Article

\title{
Consequences of Transport Low-Carbon Transitions and the Carbon, Land and Water Footprints of Different Fuel Options in The Netherlands
}

\author{
Winnie Gerbens-Leenes * and Karlieke Holtz \\ Integrated Research on Energy, Environment and Society (IREES), University of Groningen, Nijenborg 6, \\ 9747 AG Groningen, The Netherlands; karlieke.holtz@gmail.com \\ * Correspondence: p.w.leenes@rug.nl
}

Received: 3 June 2020; Accepted: 9 July 2020; Published: 11 July 2020

\begin{abstract}
Transport greenhouse gas emissions are mainly caused by the use of fossil fuels, e.g., gasoline and diesel. This case study for The Netherlands calculates how alternative fuels, e.g., electricity, hydrogen or biofuels, contribute to policy aims to decarbonize transport. Alternative fuels, produced in various ways, have different carbon (CF), land (LFs) and water footprints (WFs). This study assesses CFs, LFs and WFs for fuels $\left(\mathrm{kgCO}_{2} \mathrm{e} / \mathrm{m}^{2} / \mathrm{m}^{3}\right.$ per GJ), showing differences among fuels dependent on primary energy sources. It calculates CFs, LFs and WFs for four scenarios with different fuels. The biofuel scenario is not attractive. CFs slightly decrease, while LFs and WFs increase enormously. The electricity scenario has small CFs and the smallest LFs and WFs, but this is only when using wind or solar energy. If storage is needed and hydrogen is produced using wind energy, CFs double from 3055 to $7074 \mathrm{~kg} \mathrm{CO}_{2} \mathrm{e}$, LFs increase from $15 \times 10^{6}$ to $43 \times 10^{6} \mathrm{~m}^{2}$ and WFs from $3 \times 10^{6}$ to $37 \times 10^{6} \mathrm{~m}^{3}$ compared to the electricity scenario. The case study shows that wise fuel choices contribute to policy aims to decarbonize transport, although LFs and WFs are also important to consider. These case study results are relevant for sustainable transportation transitions worldwide.
\end{abstract}

Keywords: transport carbon footprint; transport fuels; transport energy policy; land footprint; water footprint; water-energy nexus

\section{Highlights}

- Replacing $5 \%$ of gasoline or diesel in transport with a biofuel barely reduces carbon footprints.

- Even minor biofuel use in transport causes enormous land and water footprints.

- The use of electricity in transport is more sustainable with wind or solar energy.

- It is likely that renewable electricity cannot fully supply transport so that hydrogen is needed.

- The decarbonization of transport needs fuel choices that consider resources like land and water.

\section{Introduction}

Today, climate change is considered the most important challenge of our time. However, it is not the only challenge. Environmental change also includes issues like water scarcity and food security and thus the use of land [1]. Sustainable transitions-for example, a shift towards low-carbon transportation-are essential to safeguard the Earth for future generations [2]. Globally, transport accounts for $23 \%$ of $\mathrm{CO}_{2}$ emissions, with emissions increasing with an annual growth of $2.5 \%$ between 2010 and 2015 [3]. Transport $\mathrm{CO}_{2}$ emissions, or carbon footprints (CFs), are high on the international policy agenda. Policy aims to decarbonize transport and decrease emissions from $7.7 \mathrm{Gt}^{\mathrm{CO}_{2}}$ per year in 2017 to $2 \mathrm{Gt}$ in 2050. For example, of the nationally determined contributions to the Paris Agreement, 75\% focus on the transport sector [4]. Basically, there are four ways to decrease transport 
CFs: (i) decrease transport activity; (ii) improve energy efficiency of transport modes; (iii) shift to less CF intensive transport modes; (iv) use less CF intensive fuels. Although behavioral changes are needed [5], most CF reduction scenarios focus on increasing energy efficiency and fuel shifts rather than activity reduction or modal shifts [6]. For example, the European Union (EU) promotes the use of transport fuels from renewable sources in an attempt to decrease CFs in its member states. The directive 2009/28/EC from 2009 is forcing countries like The Netherlands to derive at least $10 \%$ of their transport fuels from renewable energy sources by 2020 [7]. Initiatives include the blending of crude oil-based gasoline with bioethanol and the stimulation of transport modes using electricity [8].

A lower use of transport in combination with a shift towards more efficient transport or transport modes will certainly decrease CFs. When a shift towards less CF-intensive fuels is considered, an important issue in this respect is whether a shift away from traditional fuels towards alternative fuels using new technologies will contribute to strategies to mitigate climate change without having other environmental impacts like greater land or water use. Access to materials, processes and natural resources will nearly always encounter natural limits [2]. Hao et al. [9], for example, have shown that hydrogen fuel cell vehicles depend on the availability of platinum, a scarce natural resource with regional supply limitations. Recently, many studies have analyzed the effects of a shift from traditional transport fuels towards less CF-intensive fuels. Fuels included in these studies are biofuels, hydrogen and also electricity, which is sometimes defined as an alternative fuel, e.g., [10]. Biofuels derived from biomass might decrease CFs, but they have large land requirements. In the United States, for example, all the cropland used for maize and soybean is needed in order to produce only $12 \%$ of the gasoline and $6 \%$ of the total diesel demand [11]. A study of the land and water requirements of biofuels from algae also showed the large land and water requirements [12]. A recent study into the sustainability aspects of different generations of biofuels has shown that all generations have limitations-for example, because they do not satisfy the food-energy-water nexus [13]. These authors have concluded that it is essential to not only take CFs into account but also to consider the scale of the economy, the availability of bioresources and planetary boundaries. Biofuels are related to a relatively large water requirement, e.g., [14-16], showing the competition between water for food and water for energy. Mekonnen et al. [17] confirms that water constraints currently hardly play any role in the discussion about future energy scenarios. Surprisingly, the "greenest" electricity scenario of the International Energy Agency (IEA), i.e., the scenario with a relatively small growth in electricity demand and with the largest fraction of renewables in 2035, is associated with the largest water use [17]. When sustainable transport is promoted, not only CFs of the transport mode itself, i.e., the emissions related to transport fuel consumption, but entire production chains, from cradle to gate, need to be included in the analysis so that tradeoffs with other natural resources are also taken into account. For sustainable transport, two phases, the well-to-tank (WTT) and the tank-to-wheel (TTW) phases, need to be considered. WTT includes the production chain of a fuel and TTW the combustion of a fuel. Together, WTT and TTW are termed well-to-wheel (WTW) [18-21]. The study by Stephan and Crawford [22], for example, included a life cycle perspective, including water requirements for infrastructure for passenger transport modes in Melbourne, Australia, showing the importance of all the actors in a supply chain.

Electricity use is another option to decrease CFs because electric transport modes are more efficient than modes using traditional fuels, although consumer resistance may be important [23]. If electricity is applied to fuel transport, it is essential to generate electricity using renewable energy sources like solar or wind energy rather than applying electricity generated using fossil fuels. In Malaysia, for example, the national electricity composition is based on $40 \%$ coal, $52 \%$ natural gas and $2 \%$ crude oil, so the introduction of electric vehicles eliminates tailpipe emissions but increases emissions related to electricity generation at the same time [24]. This is also the case in China, where electric cars have become increasingly popular $[3,25]$ but where electricity is still carbon-intensive [26]. An important drawback of electricity generated from solar or wind is its intermittency, i.e., that there is no supply when the sun does not shine or when the wind does not blow and the other way around. Another 
drawback, e.g., in public transport, is the limited driving range. Electric buses, for example, already need to recharge after 200 to $250 \mathrm{~km}$ [27]. Here, hydrogen as an energy carrier might be a solution. Variable renewable electricity can be used to generate hydrogen that can be stored and applied directly in the transport sector [28], while hydrogen allows for larger traveling distances than electricity $[9,27]$.

The economy of The Netherlands, one of the countries of the EU, depends on an efficient transport system, because it is the carrier of the Dutch trading system, which reflects in the slogan "Netherlands distribution nation". Fast and reliable passenger and freight transport is vital in establishing Dutch personal visits and business relations [29]. Therefore, mobility is essential in the Dutch economic system. At the same time, Dutch policy aims at decreasing transport $\mathrm{CFs}$-for example, by encouraging consumers to buy electric cars. With transport accounting for around $27 \%$ of the total $\mathrm{CO}_{2}$ emissions in The Netherlands, the importance of a transition in this sector is evident [29]. Additionally, other environmental issues (land use, water use and $\mathrm{CO}_{2}$ emissions) in the entire production chain and during the use of a fuel, from WTT and TTW, need further investigation, because trade-offs can occur if the focus is on decreasing CFs. The so-termed environmental footprint family provides a tool to assess natural resource use and emissions so that human use of these resources remains within planetary boundaries [30]. Important footprints are the resource use footprints (e.g., blue and green water footprints and land footprints) and emission footprints (e.g., carbon footprints and grey water footprints), which can be applied from local to global levels [30] - for example, in the transportation sector. This study aims to provide an environmental analysis of transport fuels, including the use of less CF-intensive fuels, that covers three environmental footprints-the carbon, water and land footprints - of transport in The Netherlands. It takes The Netherlands as the case study area because of the importance of transport for the country, the policy initiatives to decrease transport CFs and the availability of reliable data. In addition to investigating fuels that decrease CFs in transport, this study also includes tradeoffs among natural resources, combining carbon, land and water footprints to provide an overall analysis and, in addition, to calculate the consequences of using alternative fuels like hydrogen and electricity. The study answers the following research question: "Which fuels and technologies might be applied in alternative transport fuel scenarios and what are the consequences for the carbon, land and water footprints of the transport sector in The Netherlands compared to the reference situation in 2016?".

This study focuses on the entire production chain, from well to tank (WTT), and the consumption, from tank to wheel (TTW), of transport fuels, and it calculates the carbon, land and water footprints of different fuel production methods for three alternative fuel supply scenarios, dominated by different fuels per scenario, using the situation in The Netherlands in 2016 as the basis for the calculations. Fuels, e.g., electricity, as an alternative fuel, can be produced in different ways, so that the results give a range of outcomes per scenario. Although the study uses The Netherlands as the case study area, it provides information that can be applied to other countries and regions as well-for example, to the other $27 \mathrm{EU}$ countries that need to comply with the same directive to replace $10 \%$ of their transport fuels with renewables.

\section{System Analysis}

\subsection{The Dutch Transport System}

The Dutch transport system includes passenger and freight transport. In 2016, the Dutch travelled $185 \times 10^{9} \mathrm{~km}$, or $11,000 \mathrm{~km}$ per capita per year [29]. Almost $75 \%$ of the total distance is travelled by car [29]. Annually, $560 \times 10^{6}$ tons of goods enter The Netherlands [29]. Freight transport consists of $81 \%$ road traffic (lorries) and $18 \%$ inland shipping. The other $1 \%$ is railway traffic [29].

Transport using energy is an issue of standard physics in which moving a mass-in this case, a vehicle-requires a certain amount of energy [31]. Energy use for transport depends on the efficiency of the transport mode in combination with the energy requirements of the fuel applied [31]. 


\subsection{Transport Fuels}

Energy for transport is obtained from energy sources, primary energy sources (PESs) and secondary energy carriers or transport fuels [32]. Fossil PESs include coal, crude oil and natural gas. Renewable PESs, like wood, sunlight or wind, are naturally occurring and theoretically inexhaustible [32]. PESs usually need conversion technology in order to produce a transport fuel [32]. For example, crude oil is the input of an oil refinery that produces fuels like gasoline, diesel or liquefied petroleum gas (LPG) [31]. Coal is an energy source for a coal-fired power plant that generates electricity, and wind is harnessed by a wind turbine to generate electricity [31]. When converting a PES into a fuel and then applying it in transport to cause movement, energy is lost two times. Energy losses take place not only when a PES is converted into a fuel, i.e., during the well-to-tank (WTT) phase, but also when energy is converted into work in the tank-to-wheel phase (TTW). For example, in order to produce electricity, efficiency losses occur when converting a PES, e.g., coal, to electricity. Gasoline cars have an efficiency of around $20 \%-35 \%$, which means that only $20 \%-35 \%$ of the combustion energy is converted into work (i.e., movement). Electric cars have a larger efficiency of about 77\% [33] to 95\% [31]. The ratio of usable energy (i.e., input energy minus the energy losses) and input energy are often referred to as energy efficiency [31].

In 2016, Dutch transport was mainly powered by gasoline, diesel and LPG, a mixture of butane and propane obtained from natural gas (60\%) and oil (40\%) [29]. A total of $79 \%$ of all passenger cars used gasoline and 16\% used diesel [29] (CBS, 2016). The share of new technologies, like electric and hydrogen vehicles, is small; in 2016, they were used by only $2.6 \%$ of vehicles [29]. The number of electric cars is rising rapidly, however. In 2007, 8000 electric vehicles were registered, and in 2016, the number had risen to 211,000 [29].

\subsection{Electricity for Transport}

Electric vehicles differ from conventional transport in their use of electric engines to power the vehicle instead of a combustion engine [34]. There are two types of electric vehicles, full electric vehicles (FEV) and hybrid electric vehicles, which use an electric engine in combination with a combustion engine [34]. During the 1990s, the "all electric car" gained attention for its promise of a clean fuel, classified as "zero-emission" because the use of electricity in vehicles does not involve direct $\mathrm{CO}_{2}$ emission. However, the electricity that powers the batteries is derived from renewable or fossil PESs or from a mix of both. To evaluate whether an electric vehicle has low emissions, we need to consider the whole production chain, that is, not only the TTW but also the WTT phase. This is because the electricity must also be generated by a PES with low $\mathrm{CO}_{2}$ emissions, e.g., by a renewable PES like sun or wind [35], which also need energy for the construction of wind turbines and PV (photovoltaic) panels $[20,36]$. However, there is electricity demand when the sun is not shining and the wind is not blowing, or there may be a supply when there is no demand. This is where the need for the storage of renewable energy arises, e.g., in the form of hydrogen generated by electrolysis [35].

\subsection{Hydrogen for Transport}

Hydrogen can "store" renewable electricity and is a potential fuel for transport [37]. The development of using hydrogen as a fuel is relatively new compared to electricity. Though the Dutch government has set up ambitious targets which aim for a total of 2000 hydrogen cars, 100 hydrogen buses and 20 hydrogen trucks in 2020 [38], there are only two commercially available hydrogen cars [39]. Hydrogen vehicles are in fact electric vehicles that use hydrogen $\left(\mathrm{H}_{2}\right)$ as an energy source instead of electricity [34]. The hydrogen is combined with oxygen $\left(\mathrm{O}_{2}\right)$ from the air in a fuel cell and converted to water $\left(\mathrm{H}_{2} \mathrm{O}\right)$. This conversion produces the electricity which powers the engine. Waste products are water, vapor and heat [34]. The conversion does not emit $\mathrm{CO}_{2}$. However, hydrogen can be produced by using renewable energy or fossil PESs to power the electrolysis process 
in which $\mathrm{H}_{2} \mathrm{O}$ is converted to $\mathrm{H}_{2}$ [34]. Producing hydrogen using fossil PESs can also be achieved by transforming natural gas $\left(\mathrm{CH}_{4}\right)$ or coal into $\mathrm{H}_{2}$ and $\mathrm{CO}_{2}$ under high pressure and temperatures [34].

\subsection{Biofuels}

A biofuel is a gas, liquid or solid fuel derived from presently available natural sources such as plants or (agricultural) residues. In other words, they are fuels produced from recently living plant matter, as opposed to ancient plant matter in the case of fossil fuels [40]. Biofuel use in transport is growing since the EU guidelines require that the share of renewable energy in 2020 in the transport sector is $10 \%$ [29]. Therefore, Dutch regulations require a mix of renewable energy (biofuels) and gasoline or diesel. In 2017, around $8 \%$ of the gasoline and diesel consisted of biofuels, growing by $0.75 \%$ per year towards $10 \%$ in 2020 [29]. There are three biofuel types often applied in transport: biodiesel, bioethanol and bio-CNG (compressed natural gas). Biodiesel refers to a vegetable oil or animal fat-based oil that has been converted into a fuel [40]. Biodiesel can be used instead of "fossil diesel" or blended with regular diesel for application in regular diesel engines. There are first, second and third generation biodiesels [12]. First generation biodiesels are made of vegetable oil or animal fat, and they are also used for human consumption. Second generation biodiesels are made of residues or waste streams that are not suitable for human consumption. Third generation biodiesel is made of cultivated algae and has only recently entered the biofuel market [40].

Bioethanol is a gasoline substitute mainly consisting of ethanol produced from different sources like crops or agricultural residues. It can be mixed with normal fuel, often up to $5 \%$ to $10 \%$ [34]. There are also vehicles with adjusted engines that allow for a fuel mix with $85 \%$ bioethanol. Bioethanol includes first and second generation bioethanol. First generation bioethanol is produced directly from (food) crops, e.g., from sugar beet. Second generation bioethanol includes fuels manufactured from various types of biomass-for example, from agricultural residues like straw [40].

Bio-CNG is made in a biogas digester using a relatively simple, mature technology [41]. In a large tank or digester, bacteria convert organic residues into methane by anaerobic digestion. The organic residues are diverse and include manure and agricultural crop residues. The product is referred to as bio-CNG (compressed natural gas) [41].

\subsection{Environmental Impacts of Transport Fuels}

Major contributors to climate change are greenhouse gas (GHG) emissions, in which carbon dioxide $\left(\mathrm{CO}_{2}\right)$ is the most commonly known GHG. Other GHGs include methane $\left(\mathrm{CH}_{4}\right)$, nitrous oxide $\left(\mathrm{N}_{2} \mathrm{O}\right)$ and ozone $\left(\mathrm{O}_{3}\right)$ [42]. The IPCC [43] recognizes four principal greenhouse gases related to human activities: $\mathrm{CO}_{2}, \mathrm{CH}_{4}, \mathrm{~N}_{2} \mathrm{O}$ and the halocarbons (e.g., fluorine, chlorine and bromine). In terms of transport fuels, only $\mathrm{CO}_{2}, \mathrm{CH}_{4}$ and $\mathrm{N}_{2} \mathrm{O}$ are relevant [18]. The mitigation of climate change therefore needs to focus on the reduction of all GHG emissions $\left(\mathrm{CO}_{2} \mathrm{e}\right)$. The Dutch transport system is mainly based on fossil oil products (diesel and gasoline) [29], making the transport and mobility sector responsible for $27 \%$ of all $\mathrm{CO}_{2}$ emissions in The Netherlands [29]. However, alternative transport fuels that can potentially lower $\mathrm{CFs}$ might have an impact on natural resources, i.e., on land and water [44]. The water-food-energy nexus is an approach that considers the interactions between water, land and energy, while also taking the trade-offs into account [45]. Fossil PESs often use water for extraction, while power plants need water for cooling [46]. The cultivation of biomass for biofuels requires both land and water [40], while wind turbines require space. Therefore, land and water also have a connection. Energy and land are connected in the sense that energy is used in the production and transport chain of crops. The reduction of GHGs, therefore, has effects on land and water.

The footprint family includes emission footprints, i.e., the carbon and grey water footprint, and resource use footprints, i.e., the land and blue and green water footprints [30]. The carbon footprint calculates greenhouse gas emissions into the atmosphere [47]; the grey water footprint calculates the amount of freshwater needed in order to dilute polluted water to accepted water quality standards [48]. The land footprint assesses the amount of land needed to supply human needs in physical units [49]. 
The green water footprints calculate the amount of green water (precipitation) and the blue water footprint the amount of surface or groundwater needed to produce goods or services for human consumption [48].

\section{Methods and Data}

This study calculates the effects of fuel choices in the transport system on carbon (CFs), land (LFs) and total water footprints (WFs), using The Netherlands in 2016 as a case study. The study considers electricity as an alternative fuel; although it is categorized as a fuel, it is not a real fuel from an energy perspective. The study uses four scenarios with different fuel characteristics. The study includes road transport (cars, vans, trucks, buses), railway transport and inland shipping, but it excludes aviation and overseas shipping. The study includes the fuels used in The Netherlands in 2016: diesel, gasoline, marine diesel oil, bioethanol from sugar beet, biodiesel from rapeseed oil and biogas from manure [29]. Next, it assesses the effects of alternative fuel use on CFs, LFs and WFs. This is carried out for four different scenarios, based on the following fuels: scenario 1, the reference scenario with fuel use in 2016; scenario 2, hydrogen generated by electrolysis using the PESs coal, natural gas, wind and sun (PV); scenario 3, electricity from gas, coal, wind and sun; scenario 4, first generation bioethanol from wheat and second generation bioethanol from wheat straw.

The calculations are conducted in three steps. To calculate the carbon footprint, Step 1 collects and calculates $\mathrm{CO}_{2} \mathrm{e}$ emissions and LFs and WFs for each fuel. Step 2 calculates the energy demand per scenario, and Step 3 assesses the CFs, LFs and WFs per scenario. Figure 1 shows the three calculation steps, the fuels included and the related PESs.



Figure 1. Three calculation steps, the fuels applied and the related PESs for the assessment of carbon, land and water footprints related to different fuel options for transport in The Netherlands using base year 2016 (note: wheat includes the wheat crop for first generation bioethanol and wheat straw for second generation bioethanol). 


\subsection{Step 1}

Step 1 collects and calculates the CFs, LFs and total WFs for each fuel by taking the entire fuel production chain and fuel consumption (TTW and WTT) into account. CFs, LFs and WFs are expressed per unit of energy as $\mathrm{kg} \mathrm{CO}_{2} \mathrm{e} / \mathrm{GJ}, \mathrm{m}^{2} / \mathrm{GJ}$ and $\mathrm{m}^{3} / \mathrm{GJ}$. Data on $\mathrm{CO}_{2} \mathrm{e}$ emissions were derived from the Joint Research Centre [18-21] and on PV panel and wind turbine construction from Turconi et al. [36]. For the land use of diesel, gasoline, MDO (marine diesel oil) and LPG, we used the typical land use intensity of crude oil from the United Nations Convention to Combat Desertification [50]. Data on the LFs of biofuels were taken from Börjesson and Tufvesson [51], who have provided LFs for biofuels from crops and conversion routes in Northern Europe using current cultivation practices. Data on the LFs of electricity from natural gas, coal, wind energy and solar energy were taken from Kaza and Curtis [52], who provide data ranges rather than one number. LFs and blue WFs of manure were based on data from BioEnergyFarm [53], data on hydrogen production from Mehmeti et al. [54] and data on blue WFs of diesel, gasoline, MDO and LPG from Williams and Simons [55]. Data on WFs of Dutch biofuels was extracted from Mekonnen and Hoekstra [56] and data on blue WFs of electricity from Mekonnen et al. [17] (see also Appendices A-C). For biofuels, it is important to consider the country of production, because yields and weather conditions have a significant impact on LFs and WFs. We assumed that all biofuels used were produced in The Netherlands itself, because the country produces more biofuels itself than it imports or exports [57]. For the LF and WF of wheat straw, we applied an allocation step in which the LF and WF of the total biomass of wheat was allocated over the wheat yield and the wheat residue (straw), using the method developed by Mathioudakis et al. [58], who allocated WFs over the main product and the residue according to the value and weight fraction and used a conversion efficiency of ethanol production from straw of $18.6 \%$. For the WF of hydrogen, we assumed that all hydrogen is generated by electrolysis, taking the electricity use of the conversion of water into hydrogen and oxygen of $4.8 \mathrm{kWh} / \mathrm{m}^{3} \mathrm{H}_{2}\left(1.6 \mathrm{MJ} / \mathrm{MJ} \mathrm{H}_{2}\right)$ from Wang et al. [59]. We calculated the WF of hydrogen per PES using the WF of the specific PES and added the WF of the electrolysis in which two molecules of water are converted in four molecules of hydrogen and one molecule of oxygen.

For fuels, the study used the following system boundaries. Firstly, for fuels derived from biomass, direct and indirect land use changes were excluded, e.g., emissions associated with deforestation. Secondly, the study assumed fuel production using state-of-the-art technology. The study also considered byproducts, meaning that CFs, LFs and WFs are allocated over products and byproducts according to the value and weight fraction. $\mathrm{CF}$ for natural gas transportation were considered negligible because most of the gas is from The Netherlands itself and does not need to be transported over long distances. The study included CFs for solar panel and wind turbine production, using data from Turconi et al. [36]. The WTT emission factors of solar and wind energy are due to the inclusion of the production of wind turbines and solar panels. The emissions associated with the production of the mining and extraction infrastructure of natural gas and oil are also negligible $[60,61]$ and were therefore excluded.

Appendix A gives the specific CFs for the transport fuels included, Appendix B the LFs and Appendix C the WFs.

\subsection{Step 2}

Step 2 designs three scenarios characterized by the use of a specific fuel with different PESs in The Netherlands in 2016, based on the Dutch 2016 fuel mix in the reference scenario (1). The other three scenarios are as follows: (2) the hydrogen scenario; (3) the electricity scenario; (4) the biofuel scenario. If vehicles are technically not capable of using a certain fuel, their reference fuel is used (i.e., the fuel used in the reference scenario). Table 1 shows the four scenarios, fuels and PESs. 
Table 1. Four scenarios, fuels and primary energy sources included in this study.

\begin{tabular}{|c|c|c|}
\hline Scenario & Dominant Fuel & Primary Energy Sources (PESs) \\
\hline Scenario 1 & Dutch transport fuel mix 2016 & $\begin{array}{l}\text { Diesel, gasoline, (marine diesel oil (MDO), liquefied } \\
\text { petroleum gas (LPG), bioethanol, biodiesel, biogas, } \\
\text { electricity (mix of coal, gas, solar, wind) }\end{array}$ \\
\hline Scenario 2 & Hydrogen & Electricity (natural gas, coal, wind, solar) \\
\hline Scenario 3 & Electricity & Natural gas, coal, wind, solar \\
\hline Scenario 4 & Biofuels & $\begin{array}{c}\text { Bioethanol (sugar beet, wheat, wheat straw), } \\
\text { biodiesel (rapeseed oil) }\end{array}$ \\
\hline
\end{tabular}

Step 2 calculates the total energy demand of the reference scenario $(x)$ (Joules) in The Netherlands in 2016, Etransport ( $x$ ), by summing the energy demand of fuel (a) per transport mode (s) and next summing the energy demand of all transport modes:

$$
\text { Etransport }(x)=\sum_{s=1}^{t} \sum_{a=1}^{n} \operatorname{Fuel}(a, s)
$$

Data on the fuel energy demand for transport modes were taken from Statistics Netherlands (CBS) [29], Statline [62-66] (2016) and Rijkswaterstaat [67]. The total energy demands of the scenarios differ from the total demand of the reference scenario due to differences in the energy losses during the TTW stages. The study calculated the total energy demand per scenario for Etransport (s), taking the efficiencies of the reference scenario $E(x)$ and the efficiency of the scenario $E(s)$ into account by:

$$
\text { Etransport }(s)=\text { Etransport }(x) \times E(x) \times 1 / E(s)
$$

For TTW efficiencies of transport using biodiesel, bioethanol, diesel and gasoline, we used a value of $28 \%$ from Wang [68] and Sadiq [69] et al. and a value of 37\% for hydrogen and $77 \%$ for electricity, taken from Ambel [33]. For the electric scenario, we assumed that trucks and inland shipping do not use electricity but the fuel of the reference scenario.

\subsection{Step 3}

Step 3 combines results from Step 1 and 2 to obtain the CFs, LFs and WFs per scenario. Total CFs are calculated by multiplying the energy demand of transport mode $(s)$ of scenario $(x)(\mathrm{PJ})$ for fuel $(a)$, Etransport $(x, s, a)$, by the environmental impact parameter, EimpactCO ${ }_{2}$, that correlates with the PES $(e)$ for fuel $(a)\left(\mathrm{kg} \mathrm{CO}_{2} \mathrm{e} / \mathrm{GJ}\right)$ :

$$
\mathrm{CO}_{2} \text { e emissions }(x)=\sum_{s=1}^{n} \text { Etransport }(x, s, a) \times \operatorname{EimpactCO}_{2}(e, a)
$$

The CFs are expressed as $\mathrm{MtCO}_{2} \mathrm{e}$. The total LFs and WFs are calculated in the same way and are expressed as $10^{9} \mathrm{~m}^{2}$ and $10^{9} \mathrm{~m}^{3}$.

\section{Results}

Figure 2 shows the specific carbon footprints of fuels, including the WTT and TTW emissions (kg CO $2 \mathrm{e} / \mathrm{GJ})$. 


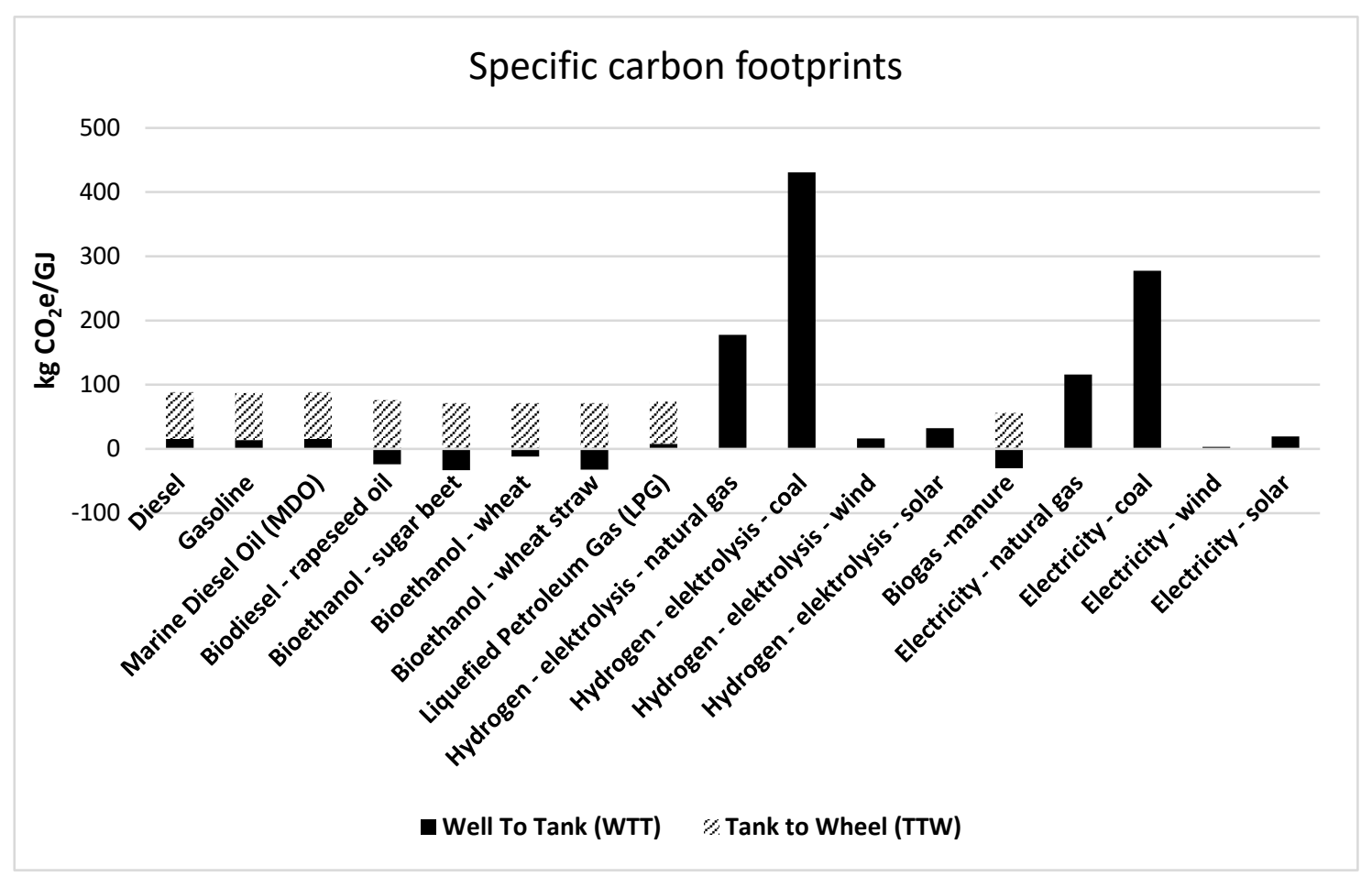

Figure 2. Specific carbon footprints of fuels, showing the well to tank (WTT) (emissions in the production chain of a fuel) and tank to wheel (TTW) (emissions during the combustion of a fuel) per gigajoule (GJ) of energy provided to the transport system $\left(\mathrm{kg} \mathrm{CO}_{2} / \mathrm{GJ}\right)$.

Figure 2 shows large differences among CFs for fuel types and related primary energy sources. Hydrogen and electricity do not have TTW emissions, while liquid and gaseous fuels do. The CFs of diesel and gasoline, the traditional liquid fuels, are smaller than some of the new fuels, like hydrogen, from electrolysis using coal or natural gas, or electricity from coal. The difference in CFs between electricity from wind and hydrogen from coal, for example, is more than a factor 20. Only when renewable PESs are used are CFs small. For the biofuels, the emissions in the WTT stage are negative, because crops take up $\mathrm{CO}_{2}$ that is released again when the fuel is combusted. Appendix A gives the $\mathrm{CFs}$ per fuel type. Figure 3 shows the specific land footprints for fuels per primary energy source $\left(\mathrm{m}^{2} / \mathrm{GJ}\right)$ on a logarithmic scale.

The differences between the land footprints (LFs) are larger in comparison to the carbon footprints (CFs). In particular, fuels derived from agriculture have large LFs. Bioethanol from wheat, for example, requires a factor 10,000 more land per unit of energy than diesel (from crude oil). Fossil fuels have the smallest LFs, while the LFs of wind and solar energy find themselves in between the two extremes. Appendix B gives the specific land footprints. Figure 4 shows the specific water footprints per fuel and related primary energy source on a logarithmic scale $\left(\mathrm{m}^{3} / \mathrm{GJ}\right)$.

WFs of biofuels have a large green component and a small grey component, while all other WFs are blue. The differences among WFs are significant. Bioethanol from rapeseed oil, for example, requires a factor 10,000 more water than diesel from crude oil. In general, WFs are the largest for fuels derived from agriculture and the smallest for electricity from wind. The figure also shows that if renewable energy is stored as hydrogen, the WF increases. Appendix $C$ gives the specific water footprints, including green, blue and grey WFs. Figure 5 shows the total energy demand per scenario, in which the reference scenario's energy demand forms the basis for the energy demand of the other three scenarios. 


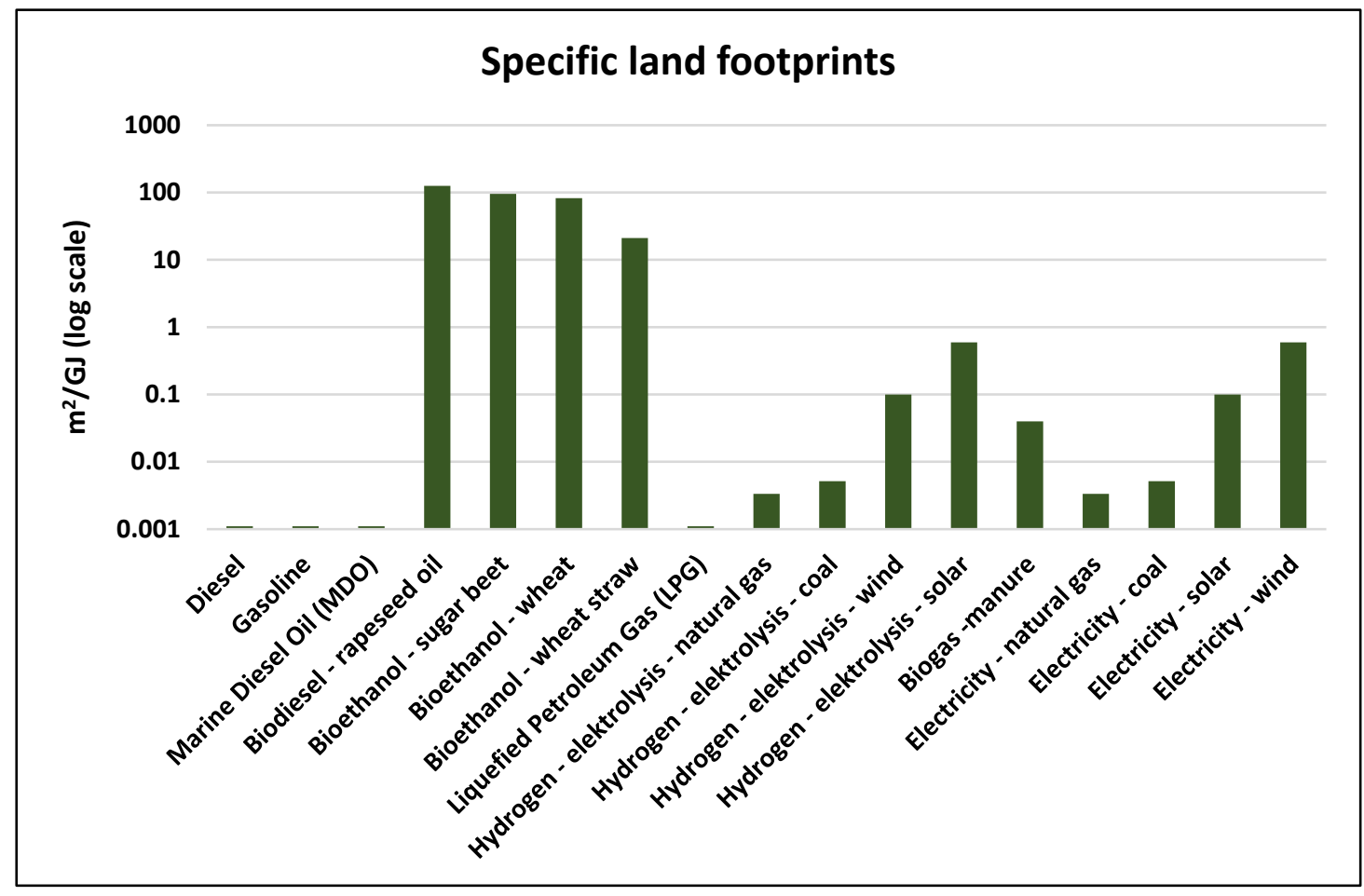

Figure 3. Land footprints per fuel and according to primary energy source ( $\mathrm{m}^{2} / \mathrm{GJ}$, logarithmic scale).

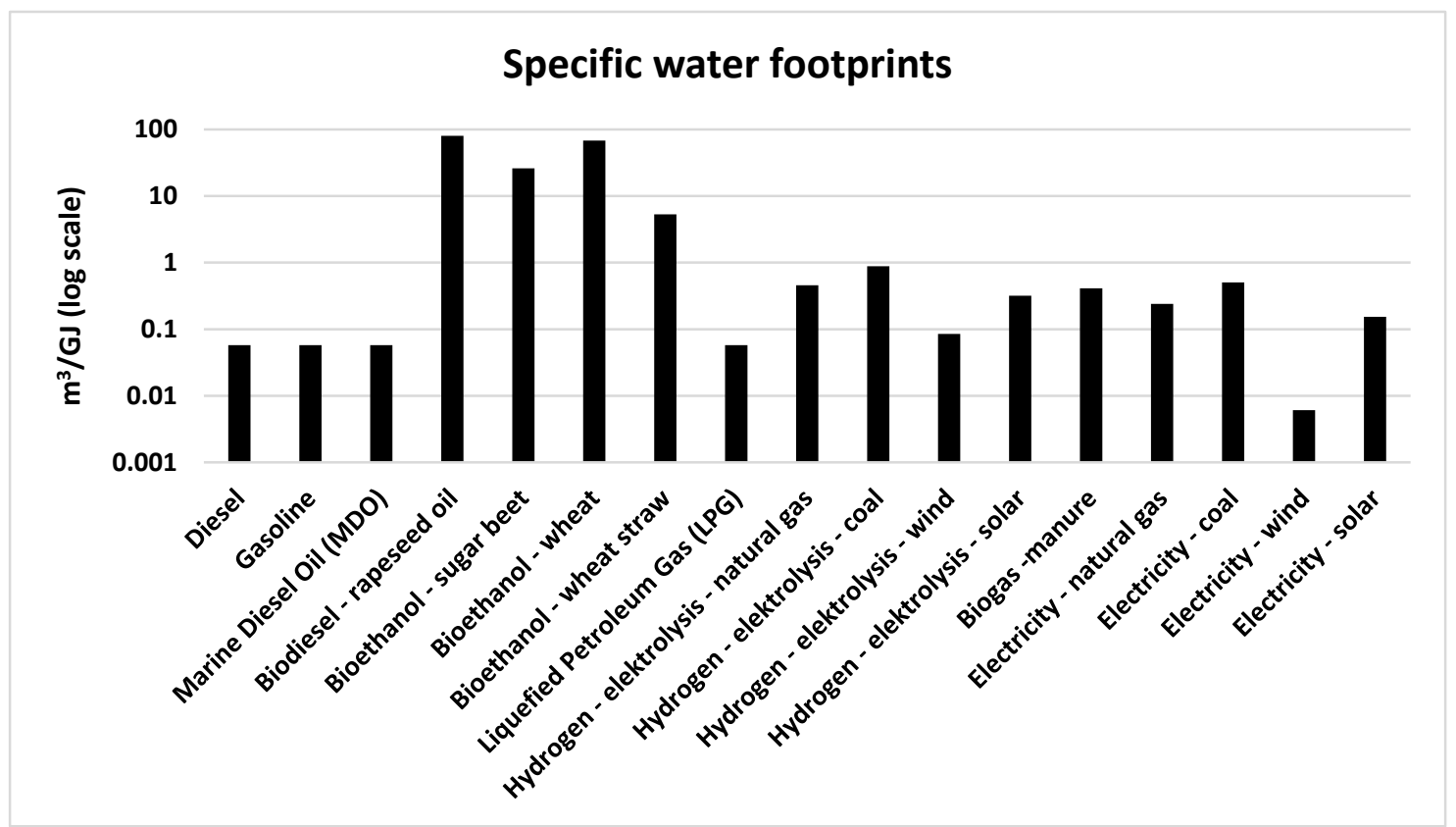

Figure 4. Specific total water footprints per fuel and related primary energy source on a logarithmic scale $\left(\mathrm{m}^{3} / \mathrm{GJ}\right)$. 


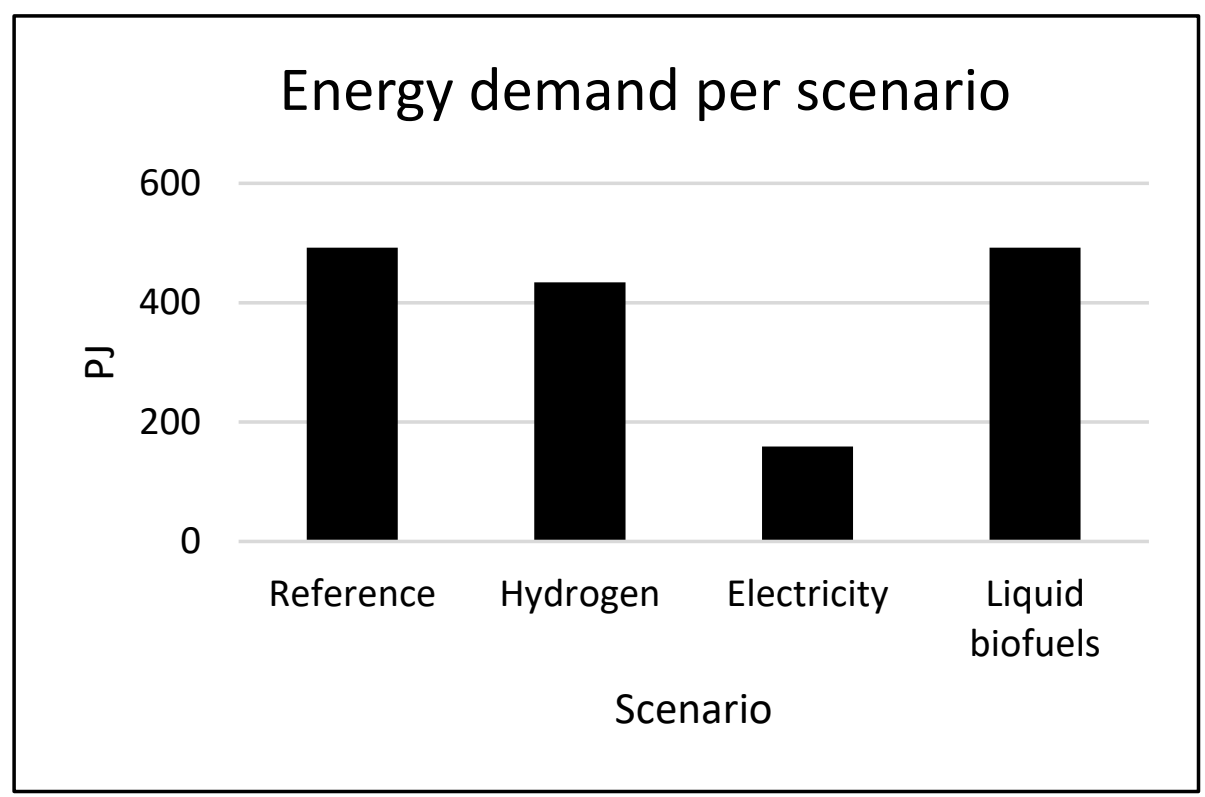

Figure 5. Total energy demand per fuel scenario for the reference situation in The Netherlands in 2016 and scenarios using hydrogen, electricity and liquid biofuels (in petajoules (PJ)).

Figure 5 shows that transport using electricity is the most energy efficient, with a total annual energy use of 159 PJ, while the reference scenario (492 PJ), the scenario with liquid biofuels (492 PJ) and the hydrogen scenario (434 PJ) are less energy efficient. If the electricity scenario is not possible, a hybrid scenario (242 PJ) is most favorable.

Figure 6a-d shows the total annual energy demand per fuel in (PJ), the annual $\mathrm{CF}\left(\mathrm{kt} \mathrm{CO}_{2} \mathrm{e}\right)$, the annual $\mathrm{LF}\left(\mathrm{m}^{2}\right)$ and annual WF $\left(\mathrm{m}^{3}\right)$ for scenario 1 (reference scenario), with regard to the situation in The Netherlands in 2016.

Figure 6a shows that energy use for transport in The Netherlands is dominated by the use of gasoline and diesel, which also contribute the most to the carbon footprint (CF). The contribution of the other fuels is small. However, Figure $6 \mathrm{c}$,d show that the use of small amounts of bioethanol and biodiesel cause large LFs and WFs compared to gasoline and diesel.

Figure 7 shows the annual CF of the four scenarios, including the reference scenario $\left(\mathrm{kt} \mathrm{CO}_{2} \mathrm{e}\right)$.

The figure shows that CFs decrease compared to the situation in 2016 if the alternatives are chosen wisely. If hydrogen that is generated using fossil fuels is applied, however, the total emissions increase. Additionally, a shift towards electricity does not always decrease the emissions substantially. This is only the case when wind and solar energy are applied. In addition, the use of bioenergy decreases CFs.

Figure 8 shows the annual LF of the four scenarios for transport fuels in The Netherlands, including the reference scenario for fuel use in 2016 on a logarithmic scale $\left(10^{9} \mathrm{~m}^{2}\right)$.

The LF of scenario 1, the reference scenario for 2016, is relatively large when compared to the LFs of scenarios 2 and 3, which do not include any biofuels. This is caused by the use of a mixture of gasoline and ethanol, and diesel and biodiesel, in The Netherlands. All LFs in biofuel scenario 4 are large compared to the LFs of scenarios 2 and 3, because this scenario relies on crops from agriculture. 

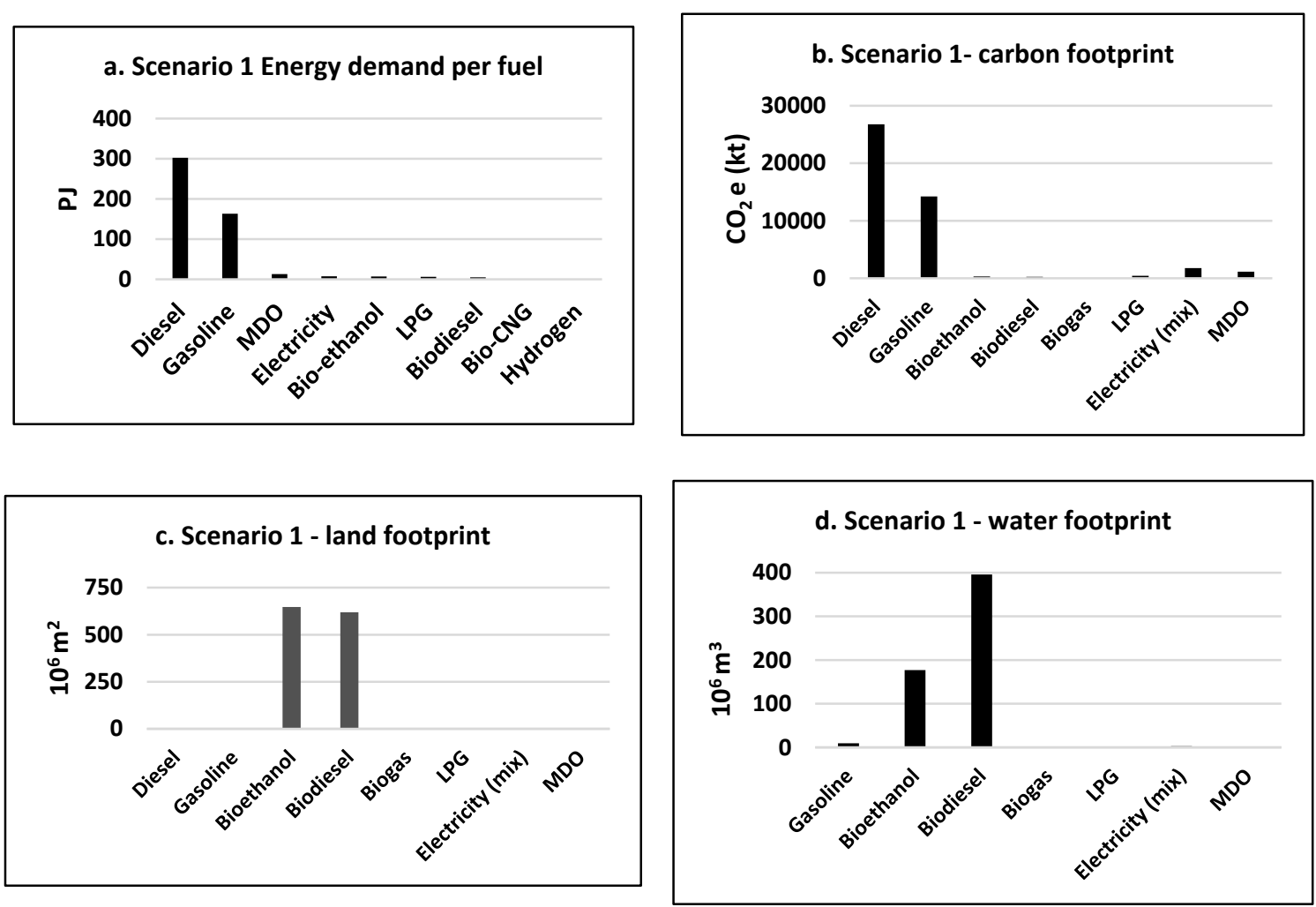

Figure 6. Here, (a) shows the total annual energy demand per fuel in scenario 1, the reference scenario (PJ); (b) shows the annual carbon footprint in scenario 1, the reference scenario $\left(\mathrm{kt} \mathrm{CO}_{2} \mathrm{e}\right)$; (c) shows the annual land footprint in scenario 1, the reference scenario $\left(\mathrm{m}^{2}\right) ;(\mathrm{d})$ shows the total annual water footprint (green, blue and grey) in scenario 1 , the reference scenario $\left(\mathrm{m}^{3}\right)$.

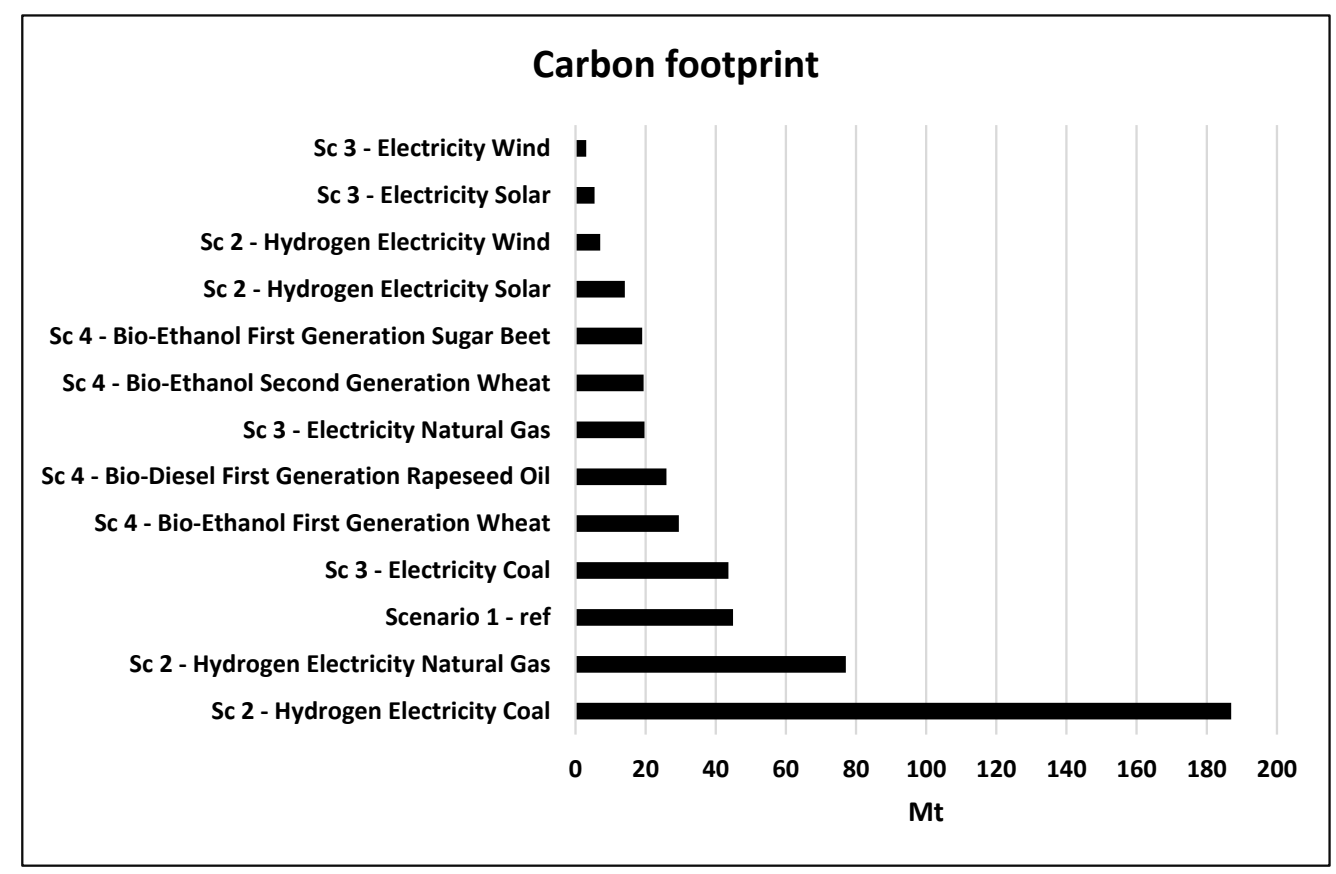

Figure 7. Annual carbon footprint of the four scenarios for transport fuels in The Netherlands, including the reference scenario for fuel use in $2016\left(\mathrm{Mt} \mathrm{CO}_{2} \mathrm{e}\right)$. 


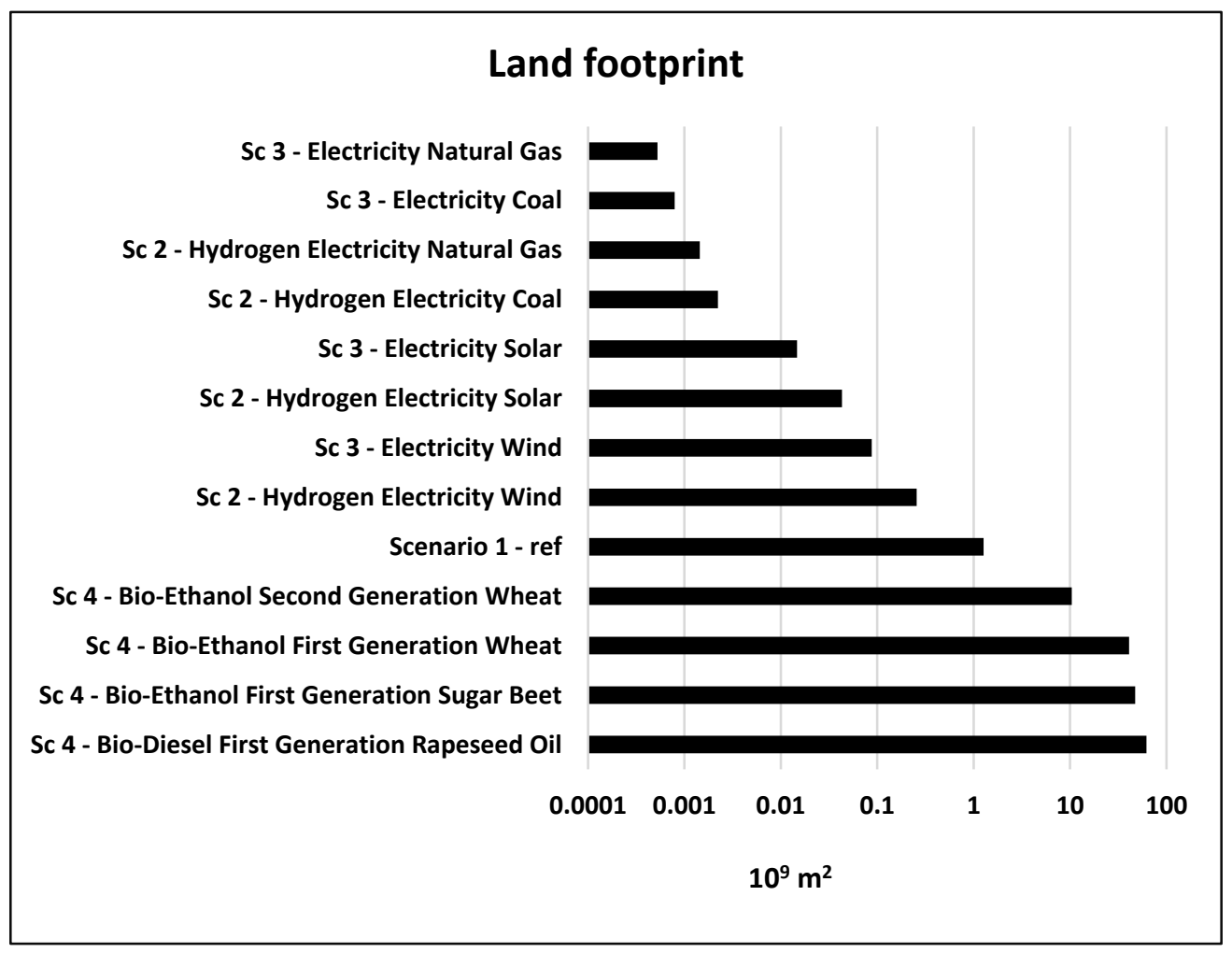

Figure 8. Annual land footprint of the four scenarios for transport fuels in The Netherlands, including the reference scenario for fuel use in $2016\left(10^{9} \mathrm{~m}^{2}\right.$ logarithmic scale).

Figure 9 shows the annual total WF of the four scenarios for transport fuels in The Netherlands, including the reference scenario for fuel use in 2016, on a logarithmic scale $\left(10^{9} \mathrm{~m}^{3}\right)$



Figure 9. Annual water footprint of the four scenarios for transport fuels in The Netherlands, including the reference scenario for fuel use in $2016\left(10^{9} \mathrm{~m}^{3}\right.$ logarithmic scale). 
Scenario 4, using crops from agriculture, has the largest WFs (mainly green), followed by scenario 1 , the reference scenario, which also includes some biofuels. The scenario using hydrogen from coal, natural gas or solar photovoltaics has blue WFs which are smaller than the reference. When electricity from wind or sun is applied, WFs are smallest.

The main message of this article is the importance of combining different environmental assessments in a complex assessment. Policy aims to decrease CFs. Figure 6 shows the present $\mathrm{CF}$ and the related LF and WF. Figure 7 shows the different options for decreasing CFs, compared to the situation in 2016 (reference scenario), indicating that not all options are favorable and that the choice of PES is important. Figures 8 and 9 show the consequences of a specific fuel choice on LFs and WFs. In order to decrease CFs, a shift towards biofuels generates large LFs and WFs. This is the case even for the reference scenario, in which a contribution of only $2.5 \%$ of the energy in the form of biofuel to the total energy use of transport generates large LFs and WFs. If a decrease in CFs is the policy's priority, the best fuel choices, if LFs and WFs are also taken into account, are electricity from wind or sun, followed by hydrogen from wind or solar.

\section{Discussion}

The study assessed the carbon, land and water footprints related to policy goals to decrease $\mathrm{CO}_{2}$ emissions for different fuel options by assuming that the transport system itself does not change. Other possible options to decrease $\mathrm{CFs}$, such as a decrease in transport activity, increased energy efficiency of transport modes or a shift towards less $\mathrm{CO}_{2}$ intensive ways of transport, were excluded. We only considered fuel shifts; however, we did include the related efficiency improvements by taking the tank-to-wheel efficiencies into account. For example, we included the larger efficiencies of electric vehicles compared to traditional cars using gasoline. This means that the scenario results might differ from a future situation in which other factors also play a role, such as technological developments in the automotive industry.

For the assessment of CFs, we mainly applied data from the Joint Research Centre (JRC) [18-21] that provide emission factors in the context of the EU. For the LFs and WFs of wind, solar and hydrogen, we used data that provide a general LF and WF. For biofuels, however, we used data for The Netherlands. In The Netherlands, crop yields are relatively large [70] and, therefore, the LFs per unit of biofuel are relatively small. In addition, WFs are also relatively small for Dutch biofuels and are dominated by green WFs [56]. This means that if the results are applied to other countries, the LFs and WFs of biofuels will probably be underestimated.

The EU policy to promote renewables for transport, such as the use of bioethanol, decreases CFs but has a large contribution to LFs and WFs. The term renewable energy is widely used, but it might be problematic in the context of sustainability [71]. This means that there is a difference between renewable energy and sustainable energy. The choice to encourage the use of renewable fuels for transport might have significant consequences for other resources, not only for land and water but also for scarce raw materials [9,71]. The Dutch policy to encourage the use of electricity for transport must also be seen in a broader context. Electric cars are more efficient than their fossil fuel-based counterparts, so the total energy use will decrease. However, it is important to consider how the electricity is generated, and the impact of this on whether or not CFs decrease. If coal is used to generate electricity, emissions do not decrease. Only if large scale wind and solar energy are applied do emissions substantially decrease. However, at present, The Netherlands does not generate these large amounts of renewable energy. The renewable energy sources, wind and solar, are crucial in reducing CFs and have acceptable impacts on land and water. However, currently, a minor proportion $(6.6 \%)$ of all energy in The Netherlands is renewable [72]. The share of renewable energy must increase in order to supply enough energy for all different energy-consuming sectors. Therefore, it is likely that the use of renewable energy (solar and wind) will become susceptible to competition between different sectors, including transport. 
Another issue is the variability of wind and solar energy or intermittency, requiring energy storage, e.g., in the form of hydrogen. This means that it is not possible to simply scale up renewable electricity production, even though this is theoretically the most efficient option. Here, hydrogen might be introduced, but with smaller efficiencies. However, the infrastructure does not yet exist for electric and hydrogen-based technologies, meaning that there are not yet enough wind turbines and solar panels to provide the entire transport system with sufficient energy. Moreover, electric and, to a larger extent, hydrogen vehicles have not yet penetrated the vehicle market, representing only $8 \%$ of the total vehicles [73], a negligible percentage of all Dutch vehicles. In addition, for hydrogen, the fueling infrastructure is not abundant enough in The Netherlands. Therefore, these options can be considered long-term solutions.

This study assessed the LF; however, land could also be defined as use of space. This is especially relevant when it comes to wind turbines, which are very commonly placed in the sea as well as on land. For example, the coastal sea area of The Netherlands (the Exclusive Economic Zone) includes approximately $1400 \mathrm{~km}^{2}$ of available space for wind turbines [74]. The required space for the wind turbines in the electricity-wind scenario is $43.2 \mathrm{~km}^{2}$, showing that the Dutch area of the North Sea is sufficient to supply enough electricity for the Dutch transport system. In line with results from the literature, e.g., $[17,40,52,75,76]$, basing the Dutch transport system on liquid biofuels is not an option, because its land and water requirements will compete excessively with our basic water and food requirements.

When WFs are put into perspective, the present transport system in The Netherlands has a green WF of $520 \times 10^{6} \mathrm{~m}^{3}$ per year, a blue WF of $31 \times 10^{6} \mathrm{~m}^{3}$ and a grey WF of $59 \times 10^{6} \mathrm{~m}^{3}$ per year. Biofuels dominate the total WF and contribute $95 \%$. If hydrogen is chosen as a transport fuel, generated by electrolysis from coal, the total WFs decrease to $381 \times 10^{6} \mathrm{~m}^{3}$ per year, but the WF is completely blue and increases tenfold compared to the blue WF of the present transport system. Electricity from wind has the smallest blue WF, at only $2.6 \times 10^{6} \mathrm{~m}^{3}$ per year. If biofuels are adopted, e.g., bioethanol from sugar beet, the WFs would increase enormously. In 2011, the green WF in The Netherlands was $17,591 \times 10^{6} \mathrm{~m}^{3}$, the blue WF $2147 \times 10^{6} \mathrm{~m}^{3}$ and the grey WF $4680 \times 10^{6} \mathrm{~m}^{3}$ [77]. These WFs are mainly external: $95 \%$ of the water is used outside the country [77]. The scenario providing ethanol from sugar beet has a green WF of 10,416 and a grey WF of $2480 \times 10^{6} \mathrm{~m}^{3}$ or $59 \%$ and $52 \%$ of the Dutch green and grey WFs in 2011, respectively. This would put a large amount of pressure on the WFs.

When LFs are put into perspective, the present Dutch transport system has a LF of $1267 \mathrm{~km}^{2}$, or $3 \%$ of the surface area of The Netherlands, at $41,000 \mathrm{~km}^{2}$ [12]. This LF is dominated by biofuel use. The scenarios based on biofuels have LFs similar to or exceeding the Dutch surface area, indicating that it is not possible to produce all fuels in The Netherlands itself. For CFs, it does not matter whether emissions take place in The Netherlands or abroad, because emissions have a global impact. For CFs, the smallest footprints are the most favorable.

The example for The Netherlands is relevant for other EU countries too. Total transport energy use in the EU in 2030 could be around 24,000 PJ per year [12] or fifty times the present Dutch energy use. All countries must comply with the same EU directive to replace $10 \%$ of the fuel with renewables, so wise choices must be made in order to prevent LFs or WFs becoming too large.

\section{Conclusions}

Traditional transport fuels, including diesel, gasoline, marine diesel oil and liquefied gasoline gas, have CFs between 74 (LPG) and 89 (diesel) $\mathrm{kg} \mathrm{CO}_{2}$ e per GJ. The CFs of bioethanol and biodiesel are smaller, at between 40 and $60 \mathrm{~kg} \mathrm{CO}$ e per GJ, and are related to energy use in the life cycle of the production of the biofuel. For electricity, emissions range between 3 (electricity from wind), 19 (solar), 116 (natural gas fired power plants) and 277 (electricity from coal fired power plants) $\mathrm{kg} \mathrm{CO}_{2} \mathrm{e}$ per GJ. This means that if energy policy promotes electric transport, it is important to apply a primary energy source with small CFs, otherwise emissions will increase rather than decrease. This is even more relevant if hydrogen is applied. CFs range between 16 (electrolysis using electricity from wind), 
32 (solar), 178 (natural gas fired power plants) and 431 (electricity from coal fired power plants) $\mathrm{kg}$ $\mathrm{CO}_{2} \mathrm{e}$ per GJ.

Traditional transport fuels have relatively small LFs, at $0.0011 \mathrm{~m}^{2}$ per GJ. Wind turbines and solar panels need space and have LFs of 0.1 and $0.6 \mathrm{~m}^{2}$ per GJ, respectively. The LFs of Dutch biofuels are large, between 21 (ethanol from wheat straw) and 125 (biodiesel from rapeseed) $\mathrm{m}^{2}$ per GJ. Dutch biofuels also have large WFs, between 5 (ethanol from wheat straw) and 80 (biodiesel from rapeseed) $\mathrm{m}^{3}$ per GJ. The WFs for hydrogen vary between 0.1 (electrolysis using wind energy) and 0.8 (electrolysis using electricity from a coal fired power plant) $\mathrm{m}^{3}$ per GJ. Other fuels have small WFs compared to biofuels.

The total energy demand for transport in The Netherlands in 2016, excluding air transport, was 492 PJ. If biofuels are applied, energy demand remains the same; for a hydrogen scenario, 434 PJ is needed. The electricity scenario is the most efficient with an energy demand of 159 PJ. From a sustainability point of view, the biofuel scenario is not attractive. The total energy demand remains the same, CFs only slightly decrease, and LFs and WFs increase enormously. This can already be observed in the reference scenario, where biofuels contribute only $2.5 \%$ to the total energy demand, but they dominate the LFs and WFs, with $99.9 \%$ of the total LF and $95 \%$ of the total WF. The electricity scenario has the smallest CFs, but only if wind or solar energy is applied. If electricity is generated using existing coal fired power plants, emissions do not decrease. This scenario also has the smallest LFs and WFs and is therefore the most favorable from a sustainability point of view. If storage is needed and hydrogen is applied, CFs for the most favorable PES, i.e., wind energy, double from 3055 to $7074 \mathrm{~kg} \mathrm{CO} 2 \mathrm{e}$, LFs increase from $15 \times 10^{6}$ to $43 \times 10^{6} \mathrm{~m}^{2}$, and WFs increase from $3 \times 10^{6}$ to $37 \times 10^{6} \mathrm{~m}^{3}$ compared to the electricity scenario.

This case study for The Netherlands shows that the use of less CF-intensive fuels contributes to energy policy aims to decarbonize transport and to substantially decrease emissions. However, trade-offs with land and water resources might occur and these need to be included in the decision-making. Other countries could also adopt these strategies.

Author Contributions: Conceptualization, W.G.-L. and K.H.; Methodology, W.G.-L. and K.H.; Validation, W.G.-L. and K.H.; Formal Analysis, K.H.; Investigation, K.H.; Resources, K.H.; Data Curation, K.H.; Writing-Original Draft Preparation, K.H.; Writing-Review \& Editing, W.G.-L.; Visualization, K.H.; Supervision, W.G.-L. All authors have read and agreed to the published version of the manuscript.

Funding: This research received no external funding.

Conflicts of Interest: The authors declare no conflict of interest.

\section{List of Abbreviations and Definitions}

$\begin{array}{ll}\text { BE1W } & \text { Bioethanol first generation Wheat } \\ \text { BE1SB } & \text { Bioethanol first generation sugar beet } \\ \text { BE2W } & \text { Bioethanol second generation wheat } \\ \text { BD1R } & \text { Biodiesel first generation rapeseed oil } \\ \text { BGM } & \text { Biogas manure } \\ \text { Bio-CNG } & \text { Bio-compressed natural gas } \\ \mathrm{CF} & \text { Carbon footprint in } \mathrm{CO}_{2} \mathrm{e} \\ \mathrm{CO}_{2} \mathrm{e} & \mathrm{CO}_{2} \text {-equivalent weighted average of all GHG emissions } \\ \mathrm{EM} & \text { Electricity mix } \\ \mathrm{ENG} & \text { Electricity natural gas } \\ \mathrm{EC} & \text { Electricity coal } \\ \mathrm{EW} & \text { Electricity wind } \\ \mathrm{ES} & \text { Electricity solar } \\ \mathrm{EW}+\mathrm{G} & \text { Electricity wind + gasoline } \\ \mathrm{EM}+\mathrm{G} & \text { Electricity mix }+ \text { gasoline } \\ \mathrm{EW}+\mathrm{B} & \text { Electricity wind + bioethanol } \\ \mathrm{EM}+\mathrm{B} & \text { Electricity mix }+ \text { bioethanol }\end{array}$


Environmental impact parameter

GHG

GJ

H2EM

H2ENG

H2EC

H2EW

H2ES

H2GNG

H2GC

$\mathrm{HFO}$

$\mathrm{J}$

LPG

MDO

MJ

Mt

PES

PJ

PV

REF

TTW

WTT

WTW

WF
The amount of $\mathrm{CO}_{2}$, water and land use per unit of energy

Greenhouse gas

Gigajoule ( $10^{9}$ Joule)

Hydrogen electricity mix

Hydrogen electricity natural gas

Hydrogen electricity coal

Hydrogen electricity wind

Hydrogen electricity solar

Hydrogen gasification natural gas

Hydrogen gasification coal

Heavy fuel oil

Joule

Liquefied petroleum gas

Marine diesel oil

Megajoule ( $10^{6}$ joule)

Megaton $\left(10^{9} \mathrm{~kg}\right)$

Primary energy source-energy sources that can be used directly, as they appear in the natural environment

Petajoule ((10 15 joule)

Photovoltaics

Reference

Tank-to-wheels emissions that occur during the combustion of a fuel in a vehicle

Well-to-tank emissions that occur in the production chain of a fuel

Well-to-wheels-TTW and WTT emissions combined

Water footprint-the total annual volume of freshwater used to produce the goods and services related to consumption

\section{Appendix A. Specific Carbon Footprints for Transport Fuels}

Table A1 gives the specific carbon footprints ( $\mathrm{kg} \mathrm{CO}_{2} \mathrm{e}$ per $\left.\mathrm{GJ}\right)$ for transport fuels, including the well-to-tank (WTT), tank-to-wheels (TTW) and well-to-wheels (WTW) footprints. Data were derived from the Joint Research Center [20] (JRC) and from Turconi et al. [36].

Table A1. Specific carbon footprints, including the well-to-tank (WTT), tank-to-wheels (TTW) and well-to-wheels (WTW) emissions. (Sources: JRC [20]; Turconi et al. [36]).

\begin{tabular}{cccccc}
\hline \multirow{2}{*}{ Fuel Type } & Reference & Fuel & \multicolumn{2}{c}{$\begin{array}{c}\text { Carbon Footprint } \\
\text { (kg CO } \text { C }_{\mathbf{2}} \text { /GJ) }\end{array}$} \\
\hline \multirow{3}{*}{ Liquid } & & WTT & TTW & WTW \\
& {$[20,36]$} & Diesel & 15.4 & 73.2 & 88.6 \\
& {$[20,36]$} & Gasoline & 13.8 & 73.4 & 87.2 \\
& {$[20,36]$} & Marine diesel oil (MDO) & 15.4 & 73.0 & 88.4 \\
& {$[20]$} & Biodiesel-rapeseed oil & -23.9 & 76.2 & 52.3 \\
& {$[20,36]$} & Bioethanol-sugar beet & -33.0 & 71.4 & 38.4 \\
& {$[20,36]$} & Bioethanol-wheat & -12.0 & 71.4 & 59.4 \\
Gaseous & Bioethanol-wheat straw & -32.2 & 71.4 & 39.2 \\
& {$[20,36]$} & Liquefied petroleum gas (LPG) & 8.0 & 65.8 & 73.8 \\
& {$[20]$} & Hydrogen electrolysis-natural gas & 177.6 & 0 & 177.6 \\
& {$[20]$} & Hydrogen electrolysis-coal & 430.8 & 0 & 430.8 \\
& {$[20]$} & Hydrogen electrolysis-wind & 16.3 & 0 & 16.3 \\
& {$[20]$} & Hydrogen electrolysis-solar & 32.4 & 0 & 32.4 \\
& {$[20]$} & Electricity-natural gas & -30.0 & 56.0 & 26.0 \\
& {$[20,36]$} & Electricity-coal & 115.8 & 0 & 115.8 \\
& {$[20]$} & Electricity-wind & 277.4 & 0 & 277.4 \\
& {$[20]$} & Electricity-solar & 3.3 & 0 & 3.3 \\
& {$[20,36]$} & mpressed natural gas (CNG)-manure & 19.4 & 0 & 19.4 \\
\hline
\end{tabular}




\section{Appendix B. Specific Land Footprints for Transport Fuels}

Table A2 gives the specific land footprints for transport fuels.

Table A2. Specific land footprints for transport fuels. (Sources: United Nations Convention to Combat Desertification (UNCCD) [50] for typical values; Börjesson and Tufvesson [51] for crops and technologies in Northern Europe; this study; BioEnergyFarm [53]; Kaza and Curtis [52]).

\begin{tabular}{cccc}
\hline Type & References & Fuel & $\begin{array}{c}\text { Land Footprint } \\
\text { ( } \mathbf{m}^{2} \text { /GJ Final Fuel) }\end{array}$ \\
\hline Liquid & {$[50]$} & Diesel & 0.001 \\
& {$[50]$} & Gasoline & 0.001 \\
& {$[50]$} & Marine diesel oil (MDO) & 0.001 \\
& {$[51]$} & Biodiesel-rapeseed oil & 125 \\
Gaseous & Bioethanol-sugar beet & 95 \\
& {$[51]$} & Bioethanol-wheat & 83 \\
& {$[51]$} & Bioethanol-wheat straw & 21 \\
& {$[51]$} & Liquefied petroleum gas (LPG) & 0.011 \\
& {$[50]$} & Hydrogen electrolysis-electricity mix & 0.004 \\
& [this study] & Hydrogen electrolysis-natural gas & 0.003 \\
& [this study] & Hydrogen electrolysis-coal & 0.005 \\
& [this study] & Hydrogen electrolysis-wind & 0.099 \\
& [this study] & Hydrogen electrolysis-solar & 0.590 \\
& [this study] & Hydrogen thermal-coal & 0.005 \\
& [this study] & Hydrogen thermal-natural gas & 0.003 \\
& [this study] & Bio-compressed natural gas (CNG)—manure* & 0.040 \\
& {$[53]$} & Electricity-natural gas & $0.002-0.005$ \\
& {$[52]$} & Electricity-coal & $0.002-0.008$ \\
& {$[52]$} & Electricity-wind & $0.286-0.897$ \\
& {$[52]$} & Electricity-solar & $0.046-0.153$ \\
\hline
\end{tabular}

* Average measurement of a biogas digester is $240 \mathrm{~m}^{3}$ with an overall capacity of $335 \mathrm{MWh}$ per year; $335 \mathrm{MWh}$ is 1205 GJ per year (BioEnergyFarm [53]). Assuming that an average bio digester has a height of $5 \mathrm{~m}$, this leaves a ground surface of $48 \mathrm{~m}^{2}$. Dividing the surface by the amount of energy generated in the digester in one year gives an environmental impact parameter of $0.04 \mathrm{~m}^{2} / \mathrm{GJ}$.

\section{Appendix C. Specific Water Footprints for Fuels}

Table A3 gives the specific water footprints for fuels.

Table A3. Specific water footprints for fuels. (Sources: Williams and Simons [55]; Mekonnen and Hoekstra [60]; Mathioudakis et al. [58]; this study; Mekonnen et al. [17]).

\begin{tabular}{|c|c|c|c|c|c|}
\hline Type & References & Fuel & $\begin{array}{l}\text { Water Footprint } \\
\left(\mathrm{m}^{3} / \mathrm{GJ} \text { Final Fuel) }\right.\end{array}$ & & \\
\hline \multirow{8}{*}{ Liquid } & & & Blue & green & grey \\
\hline & [55] & Diesel & 0.06 & 0 & n.d * \\
\hline & [55] & Gasoline & 0.06 & 0 & n.d ${ }^{*}$ \\
\hline & [55] & Marine diesel oil (MDO) & 0.06 & 0 & n.d ${ }^{*}$ \\
\hline & {$[60]$} & Biodiesel—rapeseed oil & 0 & 75 & 5 \\
\hline & {$[60]$} & Bioethanol-sugar beet & 0 & 21 & 5 \\
\hline & {$[60]$} & Bioethanol-wheat & 0 & 50 & 18 \\
\hline & {$[58]$} & Bioethanol—wheat straw & 0 & 4 & 1 \\
\hline \multirow[t]{10}{*}{ Gaseous } & {$[55]$} & Liquefied petroleum gas (LPG) & 0.06 & 0 & n.d ${ }^{*}$ \\
\hline & [this study] & Hydrogen electrolysis-natural gas & 0.46 & 0 & n.d ${ }^{*}$ \\
\hline & [this study] & Hydrogen electrolysis-coal & 0.88 & 0 & n.d ${ }^{*}$ \\
\hline & [this study] & Hydrogen electrolysis-wind & 0.08 & 0 & n.d * \\
\hline & [this study] & Hydrogen electrolysis_-solar & 0.32 & 0 & n.d $*$ \\
\hline & $* *$ & Bio-compressed natural gas (CNG)—manure & 0.41 & 0 & n.d $*$ \\
\hline & [17] & Electricity_natural gas & 0.24 & 0 & n.d * \\
\hline & [17] & Electricity-coal & 0.50 & 0 & n.d * \\
\hline & [17] & Electricity-wind & 0.01 & 0 & n.d * \\
\hline & [17] & Electricity-solar & 0.15 & 0 & n.d * \\
\hline
\end{tabular}

${ }^{*}$ n.d. = no data. ${ }^{* *}$ See calculation below in Table A4 
Table A4. Calculation water footprint Bio-compressed natural gas (CNG)—manure.

\begin{tabular}{ccc}
\hline \multicolumn{3}{c}{ Water Use Bio-CNG (Sources: BioEnergyFarm [53]) } \\
\hline $\begin{array}{c}\text { Input Capacity Installation: } 15,000 \mathrm{~kg} \text { Water Input }\left(15 \mathrm{~m}^{3}\right) . \text { Output: } \\
\text { Energy Content CNG: } 37 \mathrm{MJ} / \mathrm{m}^{3}=37,000 \mathrm{MJ}\end{array}$ \\
\hline \multirow{2}{*}{ Calculation } & 0.000405405 & $\mathrm{~m}^{3} / \mathrm{MJ}$ \\
\cline { 2 - 3 } & 0.405405405 & $\mathrm{~m}^{3} / \mathrm{GJ}$ \\
\hline
\end{tabular}

\section{Appendix D. Scenarios 1-4}

Appendix D gives the carbon footprint $\left(\mathrm{CO}_{2} \mathrm{e}\right.$ emissions in $\left.\mathrm{kt}\right)$, land footprint $\left(10^{6} \mathrm{~m}^{2}\right)$ and water footprint $\left(10^{6} \mathrm{~m}^{3}\right)$ for the four scenarios. Table $\mathrm{A} 5$ shows the energy use, $\mathrm{CO}_{2} \mathrm{e}$ emissions, land and water footprints per fuel for scenario 1, the reference scenario, i.e., the fuel use in The Netherlands in 2016.

Table A5. Energy use and carbon, land and water footprints for scenario 1, the reference scenario, i.e., fuel use in The Netherlands in 2016

\begin{tabular}{ccccc}
\hline Fuel & $\begin{array}{c}\text { Energy Use } \\
\mathbf{( P J )}\end{array}$ & $\begin{array}{c}\text { Carbon } \\
\text { Footprint (Mt) }\end{array}$ & $\begin{array}{c}\text { Land Footprint } \\
\mathbf{( 1 0}^{\mathbf{6}} \mathbf{~ m}^{\mathbf{2}} \mathbf{~}\end{array}$ & $\begin{array}{c}\text { Water Footprint } \\
\mathbf{( 1 0}^{\mathbf{6}} \mathbf{~ m}^{\mathbf{3}} \mathbf{)}\end{array}$ \\
\hline Diesel & 302.2 & 26.775 & 0.33 & 17.38 \\
Gasoline & 163.0 & 14.214 & 0.18 & 9.37 \\
Bioethanol & 6.8 & 308 & 647.62 & 176.80 \\
Biodiesel & 5.0 & 259 & 618.83 & 395.92 \\
Bio-compressed natural gas (CNG) & 0.45 & 12 & 0.02 & 0.18 \\
Liquefied petroleum gas (LPG) & 6.0 & 443 & 0.01 & 0.35 \\
Electricity (mix) & 7.4 & 1.777 & 0.03 & 2.75 \\
Marine diesel oil (MDO) & 13 & 1.149 & 0.01 & 0.75 \\
Total & 503.8 & 44.936 & 1266.83 & 603.50 \\
\hline
\end{tabular}

Table A6 shows the carbon, land and water footprints for scenario 2, the hydrogen scenario.

Table A6. Carbon, land and water footprints for scenario 2, the hydrogen scenario.

\begin{tabular}{cccc}
\hline Fuel & Carbon Footprint (Mt) & Land Footprint $\left.\mathbf{( 1 0}^{\mathbf{6}} \mathbf{~ m}^{\mathbf{2}}\right)$ & Water Footprint $\mathbf{( 1 0}^{\mathbf{6}} \mathbf{~ m}^{\mathbf{3}} \mathbf{~}$ \\
\hline Electrolysis-natural gas & 77.078 & 1.4 & 197.8 \\
Electrolysis-coal & 186.967 & 2.2 & 381.1 \\
Electrolysis-wind & 7.074 & 43.2 & 36.8 \\
Electrolysis-solar & 14.061 & 256.8 & 138.4 \\
\hline
\end{tabular}

Table A7 shows the carbon, land and water footprints for scenario 3, the electricity scenario.

Table A7. Carbon, land and water footprints for scenario 3, the electricity scenario.

\begin{tabular}{cccc}
\hline Fuel & Carbon Footprint (Mt) & Land Footprint $\left.\mathbf{( 1 0}^{\mathbf{6}} \mathbf{~ m}^{\mathbf{2}}\right)$ & Water Footprint $\left.\mathbf{( 1 0}^{\mathbf{6}} \mathbf{~ m}^{\mathbf{3}}\right)$ \\
\hline Electricity-natural gas & 19.705 & 0.5 & 37.0 \\
Electricity-coal & 43.622 & 0.8 & 76.3 \\
Electricity-wind & 3.055 & 14.7 & 2.6 \\
Electricity-solar & 5.438 & 87.6 & 24.3 \\
\hline
\end{tabular}


Table A8 shows the carbon, land and water footprints for scenario 4, the biofuels scenario.

Table A8. Carbon, land and water footprints for scenario 4, the biofuels scenario.

\begin{tabular}{cccc}
\hline Fuel & Carbon Footprint (Mt) & Land Footprint $\left.\mathbf{( 1 0}^{\mathbf{6}} \mathbf{~ m}^{\mathbf{2}}\right)$ & Water Footprint $\left.\mathbf{( 1 0}^{\mathbf{6}} \mathbf{~ m}^{\mathbf{3}}\right)$ \\
\hline $\begin{array}{c}\text { Bioethanol—first } \\
\text { generation wheat }\end{array}$ & 29.462 & 40,935 & 33,728 \\
$\begin{array}{c}\text { Bioethanol-first } \\
\text { generation sugar beet } \\
\text { Bioethanol-second } \\
\text { generation wheat straw } \\
\text { Biodiesel-first }\end{array}$ & 19.046 & 47,238 & 12,896 \\
generation rapeseed oil & 19.443 & 10,417 & 2622 \\
\hline
\end{tabular}

\section{References}

1. Collins, L.; Andrew, I.; Freimuth, E.; Zhang, S. A race we can win. One Earth 2019, 1, 1-2. [CrossRef]

2. Sarkis, J. Sustainable transitions: Technology, resources, and society. One Earth 2019, 1, 48-50. [CrossRef]

3. International Energy Agency (IEA). Tracking Clean Energy Progress 2017. Available online: https:// www.iea.org/publications/freepublications/publication/TrackingCleanEnergyProgress2017.pdf (accessed on 16 January 2019).

4. Paris Process on Mobility and Climate (PPMC). A Global Macro Road Map Outlining an Actionalble Vision towards Decarbonized, Resilient Transport. Available online: http://www.ppmc-transport.org/wp-content/ uploads/2016/04/GMR2017.pdf (accessed on 16 January 2019).

5. Chapman, L. Transport and climate change: A review. J. Transp. Geogr. 2007, 15, 354-367. [CrossRef]

6. Edelenbosch, O.Y.; McCollum, D.L.; Van Vuuren, D.P.; Betram, C.; Carrara, S.; Daly, H.; Fujimori, S.; Kitous, A.; Kyle, P.; Broin, E.Ó.; et al. Decomposing passenger transport futures: Comparing results of global integrated assessment models. Transp. Res. Part D 2017, 55, 281-293. [CrossRef]

7. Dutch Parliament (Tweede Kamer der Staten Generaal). Kamerstuk 34717 nr. 3. Available online: https://zoek.officielebekendmakingen.nl/kst-34717-3.html (accessed on 16 January 2019).

8. Nederland Elektrisch. Available online: https://nederlandelektrisch.nl/Formule-E-Team (accessed on 16 January 2019).

9. Hao, H.; Geng, Y.; Tate, J.E.; Liu, F.; Sun, X.; Mu, Z.; Xun, D.; Liu, Z.; Zhao, F. Securing platinum-group metals for transport low-carbon transition. One Earth 2019, 1, 117-125. [CrossRef]

10. Senate and House of Representatives of Energy Policy of the United States of America. Energy Policy Act of 1992. Available online: https://www.govinfo.gov/content/pkg/STATUTE-106/pdf/STATUTE-106-Pg2776.pdf (accessed on 27 June 2020).

11. Hill, J.; Nelson, E.; Tilman, D.; Polasky, S.; Tiffany, D. Environmental, economic, and energetic costs and benefits of biodiesel and ethanol biofuels. Proc. Natl. Acad. Sci. USA 2006, 103, 11206-11210. [CrossRef]

12. Gerbens-Leenes, P.W.; Xu, L.; De Vries, G.J.; Hoekstra, A.Y. The blue water footprint and land use of biofuels from algae. Water Resour. Res. 2014, 50, 8549-8563. [CrossRef]

13. Darda, S.; Papalas, T.; Zabaniotou, A. Biofuels journey in Europe: Currently the way to low carbon economy sustainability is still a challenge. J. Clean. Prod. 2019, 208, 575-588. [CrossRef]

14. Berger, M.; Pfister, S.; Bach, V.; Finkbeiner, M. Saving the planet's climate or water resources? The trade-off between carbon and water footprints of European biofuels. Sustainability 2015, 7, 6665-6683. [CrossRef]

15. Gerbens-Leenes, P.W. Green, Blue and Grey Bioenergy Water Footprints, a Comparison of Feedstocks for Bioenergy Supply in 2040. Environ. Process. 2018, 5. [CrossRef]

16. del G. Rodriguez, R.; Scanlon, B.R.; King, C.W.; Scarpare, F.V.; Xavier, A.C.; Pruski, F.F. Biofuel-water-land nexus in the last agricultural frontier region of the Brazilian Cerrado. Appl. Energy 2018, 231, 1330-1345. [CrossRef]

17. Mekonnen, M.M.; Gerbens-Leenes, W.; Hoekstra, A.Y. The consumptive water footprint of electricity and heat: A global assessment. Environ. Sci. Water Res. Technol. 2015, 1, 285-297. [CrossRef] 
18. Joint Research Centre (JRC). Well to Tank Report Version 4.a-JEC Well-To-Wheels Analysis of Future Automotive Fuels and Powertrains in the European Context. 2014. Available online: https://publications.jrc. ec.europa.eu/repository/bitstream/JRC85326/wtt_report_v4a_april2014_pubsy.pdf (accessed on 24 July 2018).

19. Joint Research Centre (JRC). Well-To-Tank Appendix 1-Version 4.a-Conversion Factors and Fuel Properties. 2014. Available online: https://ec.europa.eu/jrc/sites/jrcsh/files/wtt_appendix_1_v4a.pdf (accessed on 24 July 2018).

20. Joint Research Centre (JRC). Well-To-Tank Appendix 2-Version 4.a-Summary of Energy and GHG Balance of Individual Pathways. 2014. Available online: https://ec.europa.eu/jrc/sites/jrcsh/files/wtt_appendix_2_v4a.pdf (accessed on 24 July 2018).

21. Joint Research Centre (JRC). Well-To-Tank Appendix 4-Version 4.a-Description, Results and Input Data Per Pathway. 2014. Available online: https://iet.jrc.ec.europa.eu/about-jec/downloads (accessed on 24 July 2018).

22. Stephan, A.; Crawford, R.H. Total water requirements of passenger transport modes. Transp. Res. Part D 2016, 49, 94-109. [CrossRef]

23. Bigerna, S.; Micheli, S. Attidudes toward electric vehicles: The case of Perugia using a fuzzy set analysis. Sustainability 2018, 10, 3999. [CrossRef]

24. Onn, C.C.; Mohd, N.S.; Yuen, C.W.; Loo, S.C.; Koting, S.; Rashid, A.F.A.; Karim, M.R.; Yusoff, S. Greenhouse gas emissions associated with electric vehicle charging: The impact of electricity generation mix in a developing country. Transp. Res. Part D 2018, 64, 15-22. [CrossRef]

25. Ou, X.; Zhang, X.; Chang, S. Scenario analysis on alternative fuel/vehicle for China's future road transport: Life-cycle energy demand and GHG emissions. Energy Policy 2010, 38, 3943-3956. [CrossRef]

26. Shen, W.; Han, W.; Chock, D.; Chai, Q.; Zhang, A. Well-to-wheels life-cycle analysis of alternative fuels and vehicle technologies in China. Energy Policy 2012, 49, 296-3307. [CrossRef]

27. Bakker, S.; Konings, R. The transition to zero-emission buses in public transport. The need for institutional innovation. Transp. Res. Part D 2018, 64, 204-215. [CrossRef]

28. Balat, M. Potential importance of hydrogen as a future solution to environmental and transportation problems. Int. J. Hydrog. Energy 2008, 33, 4013-4029. [CrossRef]

29. Transport en Mobiliteit 2016; Centraal Bureau voor de Statistiek (CBS): The Hague, The Netherlands, 2016.

30. Vanham, D.; Leip, A.; Galli, A.; Kastner, T.; Bruckner, M.; Uwizye, A.; Van Dijk, K.; Ercin, E.; Dalin, C.; Brandão, M.; et al. Environmental footprint family to address local to planetary sustainability and deliver on the SDGs. Sci. Total Environ. 2019, 693, 133642. [CrossRef]

31. Rodrigue, J. Transportation and energy. In The Geography of Transport Systems - The Spatial Organization of Transportation and Mobility, 4th ed.; Rodrigue, J., Comtois, C., Slack, B., Eds.; Routledge: New York, NY, USA, 2017; ISBN 978-1138669574. Available online: https://transportgeography.org/?page_id=5717 (accessed on 1 May 2018).

32. Hanania, J.; Donev, J. Energy Education-Primary Energy. Available online: https://energyeducation.ca/ encyclopedia/Primary_energy (accessed on 2 April 2018).

33. Ambel, C.C. Roadmap to Climate-Friendly Land Freight and Buses in Europe-June 2017; Transport \& Environment: Bruxelles, Belgium, 2017.

34. Hill, N.; Hazeldine, T.; Pridmore, A.; Von Einem, J.; Wynn, D. Alternative Energy Carriers and Powertrains to Reduce GHG from Transport. Paper 2 produced as part of contract ENV.C.3/SER/2008/0053 between European Commission Directorate-General Environment and AEA Technology plc. Available online: https://www.eutransportghg2050.eu (accessed on 3 April 2018).

35. Fares, R. Renewable Energy Intermittency Explained: Challenges, Solutions, and Opportunities. Scientific American-Plug In. Available online: https://blogs.scientificamerican.com/plugged-in/renewable-energyintermittency-explained-challenges-solutions-and-opportunities/ (accessed on 3 April 2018).

36. Turconi, R.; Boldrin, A.; Astrup, T. Life cycle assessment (LCA) of electricity generation technologies: Overview, comparability and limitations. Renew. Sustain. Energy Rev. 2013, 28, 555-565. [CrossRef]

37. Pickard, W.F.; Abbott, D. Addressing the Intermittency Challenge: Massive Energy Storage in a Sustainable Future. Proc. IEEE 2012, 100, 317-321. [CrossRef]

38. Van Wijk, A. Waterstofauto Wint van Elektrische Auto-in Aantallen, Binnen 10 Jaar. Available online: https://zerauto.nl/waterstofauto-wint-van-elektrische-auto/ (accessed on 5 April 2018).

39. ANWB. Elektriciteit, Waterstof, Aardgas en Groengas, Biobrandstoffen en LPG. Available online: https://www. anwb.nl/auto/brandstof/waterstof-groengas-aardgas-alternatieve-brandstoffen (accessed on 19 March 2018). 
40. Rulli, M.C.; Bellomi, D.; Cazzoli, A.; De Carolis, G.; D'Odorico, P. The water-land-food nexus of first-generation biofuels. Sci. Rep. 2016, 6, 22521. [CrossRef] [PubMed]

41. Al Seadi, T. Biogas Handbook. Available online: http://www.lemvigbiogas.com/BiogasHandbook.pdf (accessed on 28 February 2018).

42. Michaelis, L. Global Warming Impacts of Transport. Sci. Total Environ. 1993, 134, 117-124. [CrossRef]

43. Forster, P.; Ramaswamy, V.; Artaxo, P.; Berntsen, T.; Betts, R.; Fahey, D.W.; Haywood, J.; Lean, J.; Lowe, D.C.; Myhre, G.; et al. Changes in Atmospheric Constituents and in Radiative Forcing. In Climate Change 2007: The Physical Science Basis. Contribution of Working Group I to the Fourth Assessment Report of the Intergovernmental Panel on Climate Change; Solomon, S.D., Qin, M., Manning, Z., Chen, M., Marquis, K.B., Tignor, A.M., Miller, H.L., Eds.; Cambridge University Press: Cambridge, UK; New York, NY, USA, 2007.

44. Holmatov, B.; Hoekstra, A.Y. The environmental footprint of transport by car using renewable energy. Earth Future 2020, 8, e2019EF001428. [CrossRef]

45. Reinhard, S.; Verhagen, J.; Wolters, W.; Ruben, R. Water-Food-Energy Nexus-A Quick Scan; Wageningen Economic Research: Wageningen, The Netherlands, 2017; Available online: https://www.wur.nl/upload_mm/ 1/6/f/6bec946b-792c-469b-ba07-5eec5c04b563_2017-096\%20Reinhard_def.pdf (accessed on 28 July 2018).

46. Halstead, M.; Kober, T.; Van der Zwaan, B. Understanding the Energy-Water Nexus; Energy Center The Netherlands (ECN): Sint Maartensvlotbrug, The Netherlands, 2014; Available online: https://www.ecn.nl/ docs/library/report/2014/e14046.pdf (accessed on 19 March 2018).

47. Čuček, L.; Klemeš, J.J.; Varbanov, P.S.; Kravanja, Z. Significance of environmental footprints for evaluating sustainability and security of development. Clean Technol. Environ. Policy 2015, 17, 2125-2141. [CrossRef]

48. Hoekstra, A.Y.; Chapagain, A.K.; Aldaya, M.M.; Mekonnen, M.M. The Water Footprint Assessment Manual: Setting the Global Standard; Earthscan: London, UK, 2011.

49. Kastner, T.; Erb, K.H.; Haberl, H. Rapid growth in agricultural trade: Effects on global area efficiency and the role of management. Environ. Res. Lett. 2014, 9, 034015. [CrossRef]

50. United Nations Convention to Combat Desertification (UNCCD). Global Land Outlook-First Edition. 2014. Available online: https://www.unccd.int/publications/global-land-outlook (accessed on 15 March 2018).

51. Börjesson, P.; Tufvesson, L.M. Agricultural crop-based biofuels-resource efficiency and environmental performance including direct land use changes. J. Clean. Prod. 2011, 19, 108-120. [CrossRef]

52. Kaza, N.; Curtis, M.P. The Land Use Energy Connection. J. Plan. Lit. 2014, 29, 355-369. [CrossRef]

53. BioEnergyFarm. Biolectric-Het Nieuwe Paradigm van de Biogas Sector. Available online: http://www. bioenergyfarm.eu/wp-content/uploads/2015/09/Case_NL_Belgie.pdf (accessed on 15 March 2018).

54. Mehmeti, A.; Angelis-Dimakis, A.; Arampatzis, G.; McPhail, S.J.; Ulgati, S. Life Cycle Assessment and Water Footprint of Hydrogen Production Methods: From Conventional to Emerging Technologies. Environments 2018, 5, 24. [CrossRef]

55. Williams, E.D.; Simmons, J.E. Water in the Energy Industry. An Introduction. British Petroleum (BP). Available online: https://www.bp.com/energysustainabilitychallenge (accessed on 19 May 2018).

56. Mekonnen, M.M.; Hoekstra, A.Y. The green, blue and grey water footprint of crops and derived crop products. Hydrol. Earth Syst. Sci. 2011, 15, 1577-1600. [CrossRef]

57. Dutch Emissions Authority. Conclusies Onderzoek Douanegegevens 1 Versie 113 Augustus 2017. 2017. Available online: https://www.zoekofficielebekendmakingen.nl (accessed on 28 June 2020).

58. Mathioudakis, V.; Gerbens-Leenes, P.W.; van der Meer, T.H.; Hoekstra, A.Y. The Water Footprint of second generation bioenergy: A comparison of biomass feedstocks and conversion techniques. J. Clean. Prod. 2017, 148, 571-582. [CrossRef]

59. Wang, M.; Wang, Z.; Gong, X.; Guo, Z. The intensification technologies to water electrolysis for hydrogen production-A review. Renew. Sustain. Energy Rev. 2014, 29, 573-588. [CrossRef]

60. Skone, T.J. Life Cycle Greenhouse Gas Inventory of Natural Gas Extraction, Delivery and Electricity Production. DOE/NETL-2011/1522; U.S. Department of Energy. Available online: http://www.canadiancleanpowercoalition. com/files/4713/2630/3388/LA7\%20-\%20NG-GHG-LCI.pdf (accessed on 19 April 2018).

61. Bergerson, J.; Keith, D. Life cycle assessment of Oil Sands Technologies. Institute for Sustainable Energy, Environment and Economy, Calgary. Canada. Available online: https://www.researchgate.net/profile/Joule_Bergerson/publication/ 228820377_Life_cycle_assessment_of_oil_sands_technologies/links/00b7d522eb534c1d60000000.pdf (accessed on 21 April 2018). 
62. Statline-Centraal Bureau voor de Statistiek (CBS). Vloeibare Biotransportbrandstoffen; Aanbod, Verbruik en Bijmenging. 2018. Available online: http://statline.cbs.nl/Statweb/publication/?DM=SLNL\&PA=71456ned\& $\mathrm{D} 1=\mathrm{a} \& \mathrm{D} 2=\mathrm{a} \& \mathrm{D} 3=12-14 \& \mathrm{VW}=\mathrm{T}$ (accessed on 18 January 2018).

63. Statline. Binnenvaart; Goederenvervoer, Voervoerstroom, Soort Lading. 2018. Available online: http://statline.cbs. $\mathrm{nl} /$ StatWeb/publication/?VW=T\&DM=SLnl\&PA=83019NED\&LA=nl (accessed on 26 March 2018).

64. Statline. Spoorvervoer; Goederenvervoer over Nederlands Spoor, Aan-en Afvoer, Landen. 2018. Available online: http://statline.cbs.nl/StatWeb/publication/?VW=T\&DM=SLNL\&PA=82513NED\&LA=NL (accessed on 26 March 2018).

65. Statline. Verkeersprestaties Motorvoertuigen; Kilometers, Voertuigsoort, Grondgebied. 2018. Available online: http://statline.cbs.nl/StatWeb/publication/?VW=T\&DM=SLNL\&PA=80302ned\&LA=NL (accessed on 26 March 2018).

66. Statline. Biomassa; Verbruik en Energieproductie Uit Biomassa Per Techniek. Available online: http://statline. cbs.nl/StatWeb/publication/?VW=T\&DM=SLNL\&PA=82004NED\&LA=NL (accessed on 26 March 2018).

67. Rijkswaterstaat, Ministery of Infrastructure and Water Management. Klimaatmonitor. 2019. Available online: https://klimaatmonitor.databank.nl/dashboard/ (accessed on 27 March 2018).

68. Wang, M. Estimation of Energy Efficiencies of U.S. Gasolineeum Refineries; Center for Transportation Research, Argonne National Laboratory: Lemont, IL, USA, 2008.

69. Sadiq, M.A.R.; Ali, Y.K.; Zeiny, A. Effect of ethanol-gasoline blends on exhaust and noise emissions from 4-stroke engine. Eng. Technol. 2011, 29, 1438-1450.

70. FAO. FAOSTAT, Food and Agriculture Data. 2020. Available online: http://www.fao.org/faostat/en/\#home (accessed on 30 June 2020).

71. Harjanne, A.; Korhonen, J.M. Abandoning the concept of renewable energy. Energy Policy 2019, 127, 330-340. [CrossRef]

72. Centraal Bureau voor de Statistiek (CBS). Aandeel Hernieuwbare Energie naar 6.6\%. 2018. Available online: https://www.cbs.nl/nl-nl/nieuws/2018/22/aandeel-hernieuwbare-energie-naar-6-6-procent (accessed on 15 April 2018).

73. Netherlands Enterprise Agency. Statistics Electric Vehicles in The Netherlands. 2018. Available online: https://www.rvo.nl/onderwerpen/duurzaam-ondernemen/energie-en-milieu-innovaties/elektrischrijden/stand-van-zaken/cijfers (accessed on 15 April 2018).

74. Rijkswaterstaat, Ministery of Infrastructure and Water Management. White Paper on Offshore Wind Energy. 2014. Available online: https://www.government.nl/documents/reports/2015/01/26/white-paper-on-offshorewind-energy (accessed on 16 April 2018).

75. Miller, S.A. Minimizing Land Use and Nitrogen Intensity of Bioenergy. Environ. Sci. Technol. 2010, 44, 3932-3939. [CrossRef]

76. Gerbens-Leenes, P.W. Bioenergy water footprints, comparing first, second and third generation feedstocks for bioenergy supply in 2040. Eur. Water 2017, 59, 373-380.

77. Mekonnen, M.M.; Hoekstra, A.Y. National water footprint accounts: The green, blue and grey water footprint of production and consumption. In Value of Water Research Report Series No. 50; UNESCO-IHE: Delft, The Netherlands, 2011.

(C) 2020 by the authors. Licensee MDPI, Basel, Switzerland. This article is an open access article distributed under the terms and conditions of the Creative Commons Attribution (CC BY) license (http://creativecommons.org/licenses/by/4.0/). 